\title{
Contributions of entomologists and a taxonomical bibliography of insects and other arthropods in Puerto Rico'
}

\author{
Edda L. Martínez ${ }^{2}$ \\ J. Agric. Univ. P.R. 101:33-60 (2017)
}

\begin{abstract}
This work is a compilation of the taxonomic contributions of scientists who have worked with the insect fauna of Puerto Rico and provides a bibliography of core research papers that were key to increasing knowledge of the island's insect fauna. The contributions of George N. Wolcott, Luis F. Martorell, Francisco Seín Jr., José A. Ramos-Alemar, Jenaro MaldonadoCapriles, Silverio Medina-Gaud, Juan A. Torres, José A. Mari-Mutt and Julio A. Micheli are discussed to establish how their work expanded the knowledge of the island's insect fauna. In addition, a total of $\mathbf{3 4 9}$ articles offering taxonomic information are listed, comprising all taxonomic contributions published in Puerto Rico through 2015.
\end{abstract}

Key words: Taxonomic research, taxonomic bibliography, entomological research, Puerto Rican taxonomists, Puerto Rican entomologists

\section{RESUMEN}

\section{Contribuciones de entomólogos y bibliografía taxonómica de insectos y otros artrópodos en Puerto Rico}

\begin{abstract}
Este trabajo provee una compilación de las contribuciones taxonómicas de científicos que han trabajado la fauna insectil de Puerto Rico y una bibliografía de artículos científicos que han sido clave para aumentar el conocimiento de la fauna insectil de la isla. Las contribuciones de George N. Wolcott, Luis F. Martorell, Francisco Seín Jr., José A. Ramos-Alemar, Jenaro Maldonado-Capriles, Silverio Medina-Gaud, Juan A. Torres, José A. MariMutt y Julio A. Micheli son discutidas para establecer cómo sus trabajos aumentaron el conocimiento de la fauna insectil de Puerto Rico. Además, se incluye una lista de $\mathbf{3 4 9}$ artículos que proveen información taxonómica con el fin de reunir todas las contribuciones taxonómicas que han sido publicadas en la isla hasta el 2015.
\end{abstract}

Palabras clave: investigaciones taxonómicas, bibliografía taxonómica, investigaciones entomológicas, taxónomos puertorriqueños, entomólogos puertorriqueños

${ }^{1}$ Presented at Entomology Symposium: Legacy of the International Institute of Tropical Forestry (IITF) 75th Anniversary, March 17-18, 2017, San Juan, P.R.

${ }^{2}$ Museum Registrar, Museum of Entomology and Tropical Biodiversity, University of Puerto Rico-Mayagüez Campus. 


\section{INTRODUCTION}

Taxonomy is the theory and practice of classifying organisms (ICZN, 1999). Its goal is to discover and describe new organisms, which is essential to the fundamental understanding of biodiversity, conservation practices and sustainable management of resources. Taxonomical works also serve as an inventory of local fauna that over time help determine which species have died, declined, are new to science, or represent a new report for an area. Considering the relevance of this science to other fields such as biodiversity, ecology, agriculture, conservation and medicine, it is important to know the taxonomic research in entomology that has been conducted in Puerto Rico, the influence of those taxonomic studies, and which contributions have produced the greatest increase of knowledge of the insect fauna of the island.

In Puerto Rico, research on insect taxonomy began with the creation of the Insect Collection and insect surveys conducted in the early 20th century. During the early years of the Agricultural Experiment Station (AES), established in 1910, entomologists affiliated with the institution carried out studies primarily centered on economic entomology.

Their studies rested on a comprehensive taxonomical base, recognizing the need for this research. At the same time, the New York Academy of Sciences initiated a scientific survey of Puerto Rico, which included entomological surveys that have served as the basis for successive taxonomic work. Over the years, many entomologists have contributed to the knowledge of insect fauna of Puerto Rico.

This study aims to provide a summary of the contributions of insect taxonomists, entomologists and other scientists to the field of insect taxonomy of Puerto Rico as well as to provide a complete bibliography of the taxonomical work that has been published in Puerto Rico.

\section{METHODOLOGY}

Contributions of those scientists whose work served as a basis for other taxonomical studies were selected, and the role their work played in increasing the knowledge of the insect fauna of the island is discussed. Publications, biographies, and in some cases, obituaries were examined to gather information on their contributions.

The initial taxonomic bibliography gathers all contributions in the field of insect taxonomy published on the island through 2015. To assemble the bibliography, The Journal of Agriculture of the University of Puerto Rico (JAUPR), as well as other publications, were reviewed. Ninety-nine volumes of JAUPR (from 1917 to 2015) were examined; articles that contain descriptions of new genera or species, descriptions of any developmental stage, new records of insects, taxonomical 
keys, taxonomical revisions, systematic accounts, checklists of species, distribution records, classifications, nomenclature, annotated lists, or taxonomic techniques were included in the bibliography.

\section{CONTRIBUTIONS}

\section{History and Legacy of the Agricultural Experiment Station}

The Agricultural Experiment Station (AES) was established in 1910 by the Sugar Producers' Association of Puerto Rico. Initially, research was devoted entirely to sugarcane. In 1914, the station was transferred to the Insular Government and renamed the Insular Experiment Station. In 1917, the Jones Act was passed, and the Insular Experiment Station became a division of the newly created Department of Agriculture and Labor of Puerto Rico. As a result, other crops and activities started to receive attention. In 1933, the entity was placed under the University of Puerto Rico and became the Agricultural Experiment Station of the College of Agriculture of the University of Puerto Rico, as we know it today. Cook and Otero (1937) documented these changes in a publication about the history of the AES, which is essential in understanding how these changes influenced research and sparked the interest of the scientific community affiliated with the institution.

The greatest contribution of the AES to Puerto Rican taxonomy has been the Insect Collection established in 1910 by a group of entomologists affiliated with the newly founded experiment station. These entomologists were D.L. Van Dine, W.V. Tower, E.G. Smyth, C.E. Hood and G.N. Wolcott. They began the insect collection creating the Insect Research Collection of the AES (AES-IRC), as it is known today. In the beginning, the collection housed insects collected from sugarcane research; but as different disciplines influenced research activities in the island's agriculture, the scope changed. Over the years, this collection has served as the depository for special collections, such as the Mona Island Insect Collection; insects collected by researchers on visits to other countries; Voucher Specimen Collections from ecological, biological control, and chemical control research carried out by AES researchers and faculty members of the University of Puerto Rico at Mayagüez (UPRM). The collection is also a depository for insects collected by researchers who contributed to maintaining and developing the collection. Since 1997, the Museum of Entomology and Tropical Biodiversity (MEBT, by its Spanish acronym) has been the custodian of the AESIRC (Figure 1). This collection holds approximately 200,000 organisms representing the 26 orders of insects known to occur in Puerto Rico (Franqui et al., 1997). The AES-IRC is available to researchers, faculty, and students as a reference resource. 


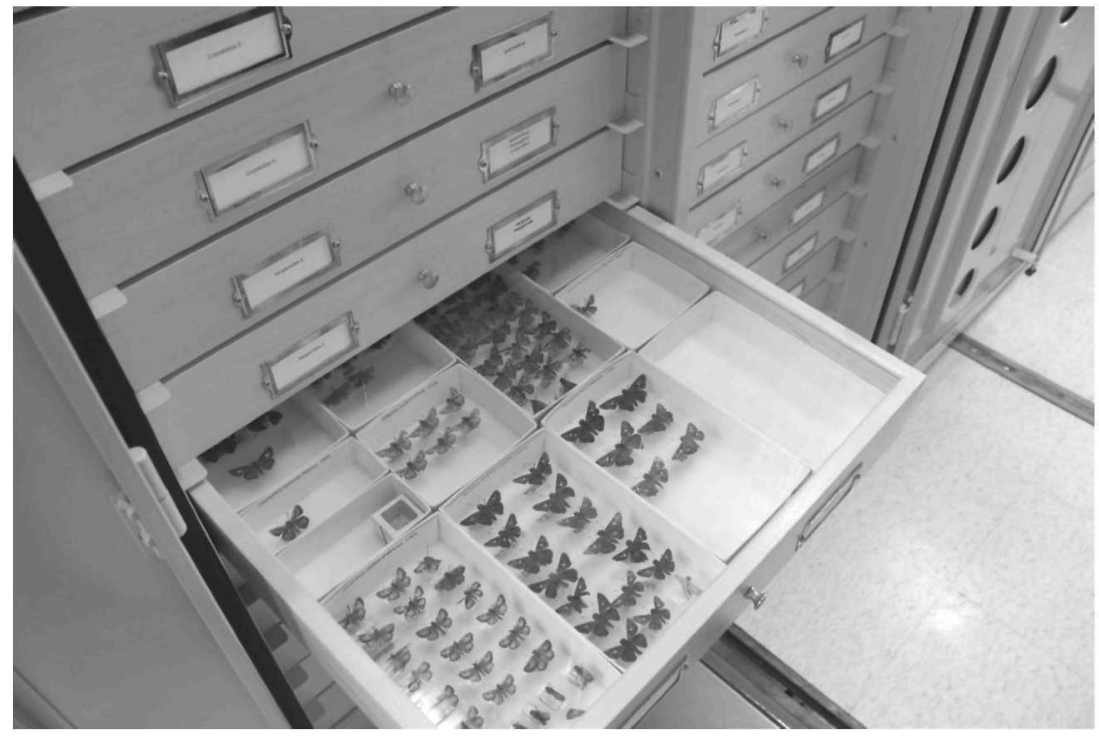

Figure 1. Lepidoptera Collection of the Agricultural Experiment Station Insect Research Collection (AES-IRC) at the Museum of Entomology and Tropical Biodiversity.

A significant number of entomologists working at the AES, some of them with a dual preparation in entomology and botany, have contributed detailed studies leaving a legacy of ecological observations (Figure 2 ), voucher specimens, graphic material and documents. This legacy is available today thanks to the culture of publishing peer-reviewed articles, circulars, bulletins, annual reviews, notes and newspaper articles.

\section{The Scientific Survey of Porto Rico and the Virgin Islands}

In 1913, three years after the establishment of the AES, the New York Academy of Sciences initiated its scientific survey of Puerto Rico and the Virgin Islands to document the natural history of the islands. Skilled investigators conducted the survey over an extended number of years in collaboration with the Departments of Agriculture and Commerce of Porto Rico and the University of Porto Rico, as "Puerto" was spelled in the early 20 th century. This survey included studies in geology, invertebrate zoology, botany, mycology, plant ecology, ornithology, mammalogy, herpetology, ichthyology, archeology, and meteorology. The results were published in 19 volumes entitled "The Scientific Survey of Porto Rico and the Virgin Islands" (New York Academy of Sciences, 1946). The four volumes dedicated to entomology covered the following groups: Diptera (Curran, 1928); Heterocera except Noctuidae, 


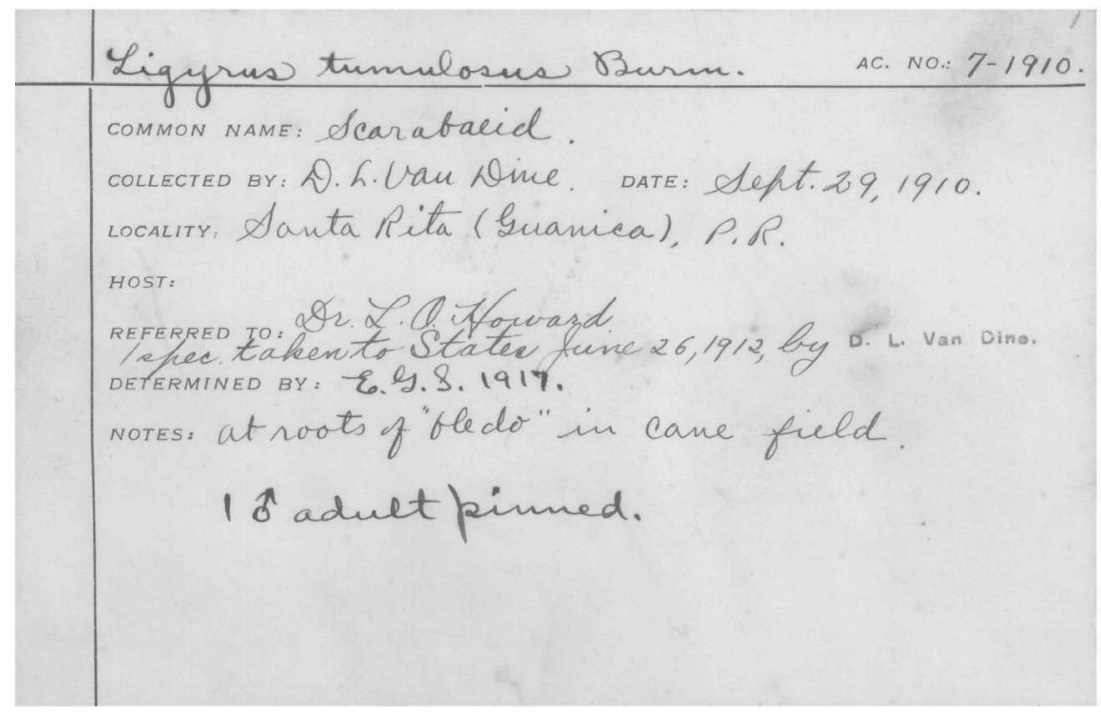

Figure 2. Catalog card of the AES-IRC with ecological observations.

Geometridae and Pyralidae (Forbes, 1930); Heterocera supplement (Forbes, 1931); Odonata (Klots, 1932); Homoptera except Sternorhyncha (Osborn, 1935); Hemiptera (Barber, 1939); Noctuidae, (Schaus, 1940a) Geometridae and Pyralidae (Schaus, 1940b); Papilionoidea and Hesperioidea (Comstock, 1944). At that time these publications were among the most comprehensive annotated lists of the insects of Puerto Rico. The information in each volume varies from author to author, but most include descriptions and diagnosis for genus and species, collection date, notes from the authors, drawings, photographs and revised keys to genera and species. It is a taxonomic reference that has served as a basis for successive taxonomic works. Unfortunately, some orders of insects such as Coleoptera and Hymenoptera were not examined.

In 1996, the New York Academy of Sciences published a revision entitled "The Scientific Survey of Puerto Rico and the Virgin Islands: An Eighty-Year Reassessment of the Island's Natural History". It provides a summary of the status of the data for each discipline, the accomplishments and lacunae of the survey, and recommendations for further work (Berríos-Ortiz, 1997).

\section{Dr. George N. Wolcott}

George N. Wolcott has been recognized as the Father of Puerto Rican Entomology. His legacy includes more than 200 scientific publications 
and manuscripts (Lawrence, 2000) that serve as a constant reference for scientists. In addition, he contributed to an increase in accession numbers in the AES-IRC, a continuous cadaster of insect fauna of the island and descriptions of species of major economic importance. He left a rich legacy of scientific collaboration and contributions to Puerto Rican and Caribbean entomology. His research on the mole crickets, white grub, and other pests provided solutions to entomological problems in the Caribbean that benefited agriculture in Puerto Rico and the continental United States (Lawrence, 2000).

In 1923, Wolcott published the first preliminary list of insects of Puerto Rico titled "Insectae Portoricensis". In 1936, he published "Insectae Borinquenses", a revised and corrected list of "Insectae Portoricensis". In 1948, he published "The Insects of Puerto Rico", an annotated list of four volumes with descriptions, collection data, collectors and collection methods for 16 orders. The "Insects of Puerto Rico" is considered his greatest taxonomic legacy (Lawrence, 2000). Wolcott's publications have contributed to a better knowledge of the local fauna and have served as a basic reference for researchers following him.

\section{Dr. Luis Francisco Martorell}

Luis Francisco Martorell's legacy includes 93 peer-reviewed publications, 28 in taxonomy, and approximately 450 newspaper articles about horticulture, entomology, botany, zoology and general gardening (Medina-Gaud, 2002). Martorell was the first Puerto Rican to obtain a doctoral degree in entomology. While studying for his doctorate at Ohio State University, he met Dr. John S. Caldwell, a North American entomologist and classmate, with whom he later worked for two years studying the Homoptera of Puerto Rico and adjacent islands (Medina-Gaud, 2002). This work appears in several taxonomic publications about the Auchenorrynchus of Puerto Rico.

Martorell noticed that host plant information for each insect species was variable and incomplete, an observation that influenced him to record host plant relationships in all of his manuscripts. In 1945 he published "A survey of the forest insects of Puerto Rico- Part I \& II", a compilation of insect species affecting forest, shade and ornamental trees. This publication was an attempt to assemble all the information available in the literature about Puerto Rican insect and host plant relationships (Martorell, 1976). Later he published "Annotated Food Plant Catalog of the Insects of Puerto Rico" (1976) to cover the insects affecting shrubs, vines, weeds, grasses, palms, trees and other plants. In this publication Martorell indicates that he only includes insects of economic importance or capable of inflicting dam- 
age to the host plant, leaving a gap of information about other insects associated with the pest or host plant such as parasites or predators (Martorell, 1976).

In 1973, he published "The Insects of Mona Island, Puerto Rico" as part of an assessment of the natural and historical resources of Mona and Monito islands; this assessment was conducted by the Environmental Quality Board of Puerto Rico. Martorell used as a reference previous studies conducted on Mona Island by Ramos (1946). He summarized the scientific activity on Mona Island and reported all new species found during previous expeditions. He used biodiversity and endemism to recommend the conservation of the island, providing a good example of how taxonomy served as a basis for conservation. Two other major contributions, co-authored by Martorell, are "Preliminary list of the insects of Desecheo Island, Puerto Rico" (1974) and "The insects of Caja de Muerto Island" (1974), both annotated lists of the insect fauna of the islands, considered great contributions to the knowledge of insect fauna of the Archipelago of Puerto Rico.

Under his leadership, recognized entomologists from different universities and museums in the United States came to Puerto Rico to study insects and other arthropods of economic importance, increasing knowledge of the fauna of the island (Medina-Gaud, 2002). Due to his continuous interest and collaboration with other entomologists, he has been honored with one genus, 11 insect species, and one species of mite bearing his name (Medina-Gaud, 2002). In 1972 the Board of Trustees of the University of Puerto Rico granted him the distinction of Emeritus Professor at the College of Agricultural Sciences, Mayagüez Campus, for his contributions to entomological knowledge.

\section{Francisco Seín Jr.}

Francisco Seín Jr. obtained a bachelor's degree in entomology from Cornell University in 1920 becoming the first Puerto Rican entomologist. He worked as an assistant entomologist at the Agricultural Experiment Station where he collaborated closely with Wolcott. His contributions to taxonomy include two peer-reviewed articles and two circulars, on the topics of sugarcane insects (1930), fruit flies (1933), cockroaches (1923), and bees (1923), respectively. He also coauthored many other publications, but his drawings and aquarelles of insects, some used by Wolcott in his publications, were his biggest legacy. Seín's aquarelle of an adult of Scapteriscus didactylus (labeled S. vicinus), Larra bicolor (labeled Larra americana) and that of the larva of Larra on Scapteriscus have been preserved under the custody of MEBT. 


\section{Dr. José A. Ramos-Alemar}

The studies of José A. Ramos-Alemar on the taxonomy of Homoptera are considered a genuine contribution to scientific knowledge, earning him grants from the National Science Foundation and the Shell Company. Among his earliest contributions the following publication stands out: "The Insects of Mona Island West Indies" (1946). It is a remarkable revision of the insect fauna of the island including distributions, richness and host plants. This publication supported information Martorell (1973) used to justify the preservation of Mona Island. Later in his career Ramos-Alemar specialized in the taxonomy of auchenorrhynchous hemipterans (Franz and Yusseff-Vanegas, 2009). In 1957 he published "A Review of the Auchenorrhynchous Homoptera of Puerto Rico", covering the families Membracidae, Cicadidae, Cercopidae and Kinnaridae, which completed the revision of Auchenorrhyncha initiated by Caldwell and Martorell in 1950 (Ramos, 1957).

José A. Ramos-Alemar officially established the UPRM Insect Collection in 1946 and acted as its primary curator until the late 1980s (Franz and Yusseff-Vanegas, 2009). According to Franz and YusseffVanegas (2009), he was responsible for acquiring more than $60 \%$ of all the insect specimens housed at UPRM, proving him to be an outstanding insect taxonomist and collector. In 1989 the Board of Trustees of the University of Puerto Rico granted him the distinction of Emeritus Professor of the College of Arts and Sciences at Mayagüez for his contributions to entomology for Puerto Rico and the Caribbean.

\section{Dr. Jenaro Maldonado-Capriles}

Prolific author Jenaro Maldonado-Capriles published more than 150 articles on Neotropical insects, including those of medical-veterinary and agricultural importance. According to Santiago-Blay (1997), he worked as an entomologist for the Bureau of Malaria Control for the State Health Department, which led him to write his first publication: "The fleas of Puerto Rico" (1945). After completing his doctorate he focused on the hemipteran families Cicadellidae, Miridae, and Reduviidae. His major contribution to insect taxonomy was his 694page "Systematic Catalogue of the Reduviidae of the World" (1990). Another important work is "The Miridae of Puerto Rico", published in 1969 and supplemented by additions and corrections in 1991. His last contribution (Maldonado, 1996) was a brief but incomplete summary of all the taxonomic contributions for 25 orders of insects until 1993. He wrote this article intending to show that intensive collecting remains to be done in the Caribbean region (Maldonado, 1996).

Maldonado's private insect collection involved more than 18,000 specimens. Most of the primary types are deposited in the National Mu- 
seum of Natural History of the Smithsonian Institution in Washington, D.C. (Santiago-Blay, 1997). He received the maximum recognition given a taxonomist, with one genus and 22 species named in his honor.

\section{Dr. Silverio Medina-Gaud}

Silverio Medina-Gaud produced more than 80 publications, each considered a great contribution to the field of entomology in Puerto Rico, especially in taxonomy. His first publication in taxonomy was his master's degree research, "The Thysanoptera of Puerto Rico" (1961), in which he described seven new species. In 1978, his doctoral dissertation titled "The Muscidae of Puerto Rico" was published, and in 2006, a revised version was published. This revision includes information and descriptions of 52 species of muscids recognized from Puerto Rico, with seven of the species described as new to science (Medina-Gaud, 2006). As a result, he achieved the most complete and representative collection of thrips and muscids of Puerto Rico, which is deposited in MEBT.

In 1977, he published the first Spanish-language guide to collecting, preserving and mounting insects and other arthropods, a useful guide for professors, students and others with an interest in this discipline. In collaboration with Maldonado-Capriles, he produced several publications, among those worth mentioning, the first illustrated (Figure 3) laboratory manual of harmful and beneficial insects of Puerto Rico (MaldonadoCapriles and Medina-Gaud, 1985).

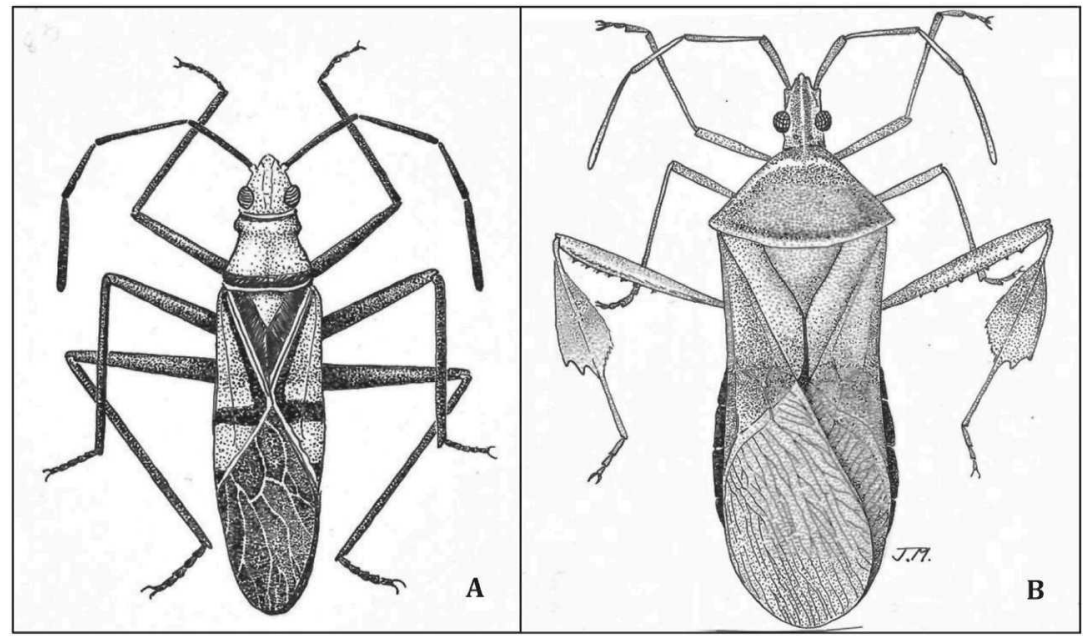

Figure 3. Original drawings of the first illustrated manual of the harmful and beneficial insects of Puerto Rico (Maldonado and Medina, 1985). (A) Dysdercus andreae (L.) (Hemiptera: Pyrrhocoridae) and (B) Leptoglossus gonara (L.) (Hemiptera: Coreidae). 
In collaboration with other members of the Crop Protection Department, UPRM, he maintained and increased the AES-IRC to more than 200,000 specimens. His contributions include descriptions of more than 15 new species and more than 200 new reports of species not previously reported on the island. Five new species have been named in his honor. For his contributions to entomological knowledge, in 2005 the Board of Trustees of the University of Puerto Rico granted him the distinction of Emeritus Professor of the College of Agricultural Sciences at UPR's Mayagüez Campus.

\section{Dr. Juan A. Torres}

Juan A. Torres was a professor in the Biology Department of the University of Puerto Rico at Bayamón specializing in entomology and ecology. The focus of his research was taxonomy and ecology of ants, but he also worked with wasps, termites and other groups of insects. According to Lugo (2016), Torres used empirical fieldwork, sagacious observations and experimentation to advance the taxonomy and ecology of ants in Puerto Rico. The result was new species and genus descriptions, taxonomical revisions, new synonyms and new reports of species, as well as documentation of new ecological aspects and the behavior of various taxonomic groups (Lugo, 2016).

Of the 34 publications by Torres, "Insects of the Luquillo Mountains, Puerto Rico", published in 1994, is noteworthy. This report is a revision of the literature of forest entomology with information on basic insect ecology, forest and wood insects, taxonomy and systematics.

In memory of Juan Torres, Julio A. Genaro and Nico M. Franz published the paper "The bees of Greater Puerto Rico (Hymenoptera: Apoidea: Anthophila)" in 2008. Juan Torres, along with Roy Snelling, collaborated on the initial version of the manuscript (Genaro and Franz, 2008). They revised previous relevant studies and provided an annotated catalog with information about the origin and distributional patterns of 39 species of bees that occur in Puerto Rico and adjacent islands, including new reports and nomenclature corrections.

\section{Dr. José A. Mari-Mutt}

Professor of the Department of Biology at UPRM, José A. MariMutt wrote two books, 11 general interest articles and more than 70 peer-reviewed articles in entomology. His legacy includes 65 papers on the taxonomy of springtails, a collection of nearly 3,500 slides of primarily Neotropical Collembola (Franz and Yussef-Vanegas, 2009); and as coauthor, "A Catalog of the Neotropical Collembola" (1990), which lists 959 species in 158 genera with synonyms. 


\section{Prof. Julio A. Micheli}

Julio A. Micheli, avid beetle collector and art professor at the Pontifical Catholic University of Puerto Rico in Ponce, has built a collection exceeding 2,000 specimens of Puerto Rican cerambycids within a span of over 30 years (Micheli, 2010). Other contributions include peer-reviewed articles with descriptions of new species, taxonomical keys, remarkable drawings of each species described, and morphological structures. His biggest legacy is the book "Longicornios de Puerto Rico" (2010) where he drew in pencil 72 cerambycids from his collection. His daughter, Dr. Charyn Micheli, a Coleoptera taxonomist working at the Smithsonian Institution, coauthored an article with Dr. Steven Lingafelter where they described one new genus and four new species of Cerambycidae. One species described in the paper was named in honor of her father, Elateropsis julio Lingafelter and Micheli (Lingafelter and Micheli, 2004).

\section{BIBLIOGRAPHY OF PUERTO RICAN INSECT TAXONOMY}

All taxonomical references published over 98 years -from 1917 to 2015- are listed in the Bibliography to provide an insight into the taxonomical work published by entomologists who have conducted research in Puerto Rico. A total of 349 articles with taxonomic information are listed, including circulars, bulletins, peer-reviewed articles and books. Of the 26 orders of insects known to occur in Puerto Rico, the following 17 orders have been found to be related to taxonomy (number of published papers in parentheses): Protura (1), Collembola (43) Thysanura (1), Ephemeroptera (1), Odonata (1), Orthoptera (1), Isoptera (4), Blattodea (1), Hemiptera (113), Thysanoptera (13), Phthiraptera (2), Coleoptera (33), Neuroptera (1), Hymenoptera (13), Lepidoptera (21), Siphonaptera (1), Diptera (29). In addition to the aforementioned orders of insects, 19 articles related to arthropods such as Acarina and Arachnida have been published. Another 57 articles have included taxonomy-related information about multiple orders of insects. In general, the best and most widely studied orders are Collembola and Hemiptera, based on publications by Mari-Mutt (Collembola) and Maldonado-Capriles (Hemiptera). The following references are those related to insect taxonomy in Puerto Rico.

Abreu, E., 1982. Adactylidium sp. (Acarina: Pyemotidae), a new record of a predatory mite of thrips eggs in Puerto Rico. J. Agric. Univ. P.R. 66: 310.

Abreu, E., A. Armstrong, V. González, A. Bosques and E. Acevedo, 2003. La mosca asiática del gandul, Melanagromyza obtusa (Malloch) (Diptera: Agromyzidae), una nueva plaga del gandul en Puerto Rico. J. Agric. Univ. P.R. 87: 65-67.

Abreu, E., J. Cardona-Colón and I. Cabrera-Asencio, 2011. Forcopyia eriophora Williston (Diptera: Ceratopogoniidae) nuevo ectoparásito de Papilio demoleus L. (Lepidoptera: Papilionidae) en Puerto Rico. J. Agric. Univ. P.R. 95: 233-235. 
Abreu, E. and G. I. Garris, 1984. Notes on the ectoparasites of the cattle egret in Puerto Rico. J. Agric. Univ. P.R. 68: 113-114.

Abreu, E., S. Medina-Gaud and J. Maldonado-Capriles, 1987. New records of mites for Puerto Rico. J. Agric. Univ, P.R. 71: 399-402.

Abreu, E. and S. Moyá, 1995. El culebrón de Puerto Rico, Epicrates inornatus (Reptilia: Boidae), un nuevo hospedero de Ornithodoros puertoricensis (Acari: Argasidae) en Puerto Rico. J. Agric. Univ. P.R. 79: 91-92.

Alexander, C. P., 1939. New or little-known species of West Indian Tipulidae (Diptera) IV. J. Agric. Univ. P.R. 23: 91-129.

Alexander, C. P., 1937. New or little-known species of West Indian Tipulidae (Diptera) III. J. Agric. Univ. P.R. 21: 523-534.

Alexander, C. P., 1937. New or little known species of West Indian Tipulidae (Diptera) II. J. Agric. Univ. P.R. 21: 179-190.

Alexander, C. P., 1936. New or little-known species of West Indian Tipulidae (Diptera) I. J. Agric. Univ. P.R. 20: 877-882.

Alexander, C. P., 1932. The crane-flies of Porto Rico. J. Dept. Agric. Labor P.R. 16: 347387.

App, B. A., 1938. Euxesta stigmatias Loew, an otitid fly infesting ear corn in Puerto Rico. J. Agric. Univ. P.R. 22: 181-188.

Armstrong, A. M., 1994. Additional new records of armyworms (Spodoptera frugiperda \& S. exigua) attacking cabbage in Puerto Rico. J. Agric. Univ. P.R. 78: 69-70.

Armstrong, A. M., 1994. Spodoptera sunia (Gueneé) (Lepidoptera: Noctuidae): A new record of attack on cabbage in Puerto Rico. J. Agric. Univ. P.R. 78: 67-68.

Armstrong, A. M., H. Ruiz and A. Pantoja, 1990. Anticarsia gemmatalis Hübner (Lepidoptera: Noctuidae): A new pest attacking pigeon pea in Puerto Rico. J. Agric. Univ. P.R. 74: 93-94.

Banks, N., 1938. Antillean Ascalaphidae. J. Agric. Univ. P.R. 22: 177-180.

Barber, H. G., 1939. Insects of Porto Rico and the Virgin Islands: Hemiptera-Heteroptera (excepting the Miridae and Corixidae). In: Scientific Survey of Porto Rico and the Virgin Islands. Vol 14, Pt 3. New York: New York Academy of Sciences. pp 263-441.

Barbosa, P., A. E. Segarra-Carmona and W. Colón-Guasp, 1986. Eumecosomyia nubila (Weidemann), a new otitid in Puerto Rico, with notes on the habits of the dipteran species complex of corn. J. Agric. Univ. P.R. 70: 155-156.

Bartlett, K. A., 1938. A drynid parasite attacking Baldulus maidis in Puerto Rico. J. Agric. Univ. P.R. 22: 497-498.

Bennet, F. D., 1999. Vibrissina sp. (Diptera: Tachinidae) a parasite of the seagrape sawfly Sericoceros krugii (Hymenoptera: Argidae) in Puerto Rico: Anew record. J. Agric. Univ. P.R. 83: 75-78.

Berríos-Ortiz, A., 1997. The Scientific Survey of Puerto Rico and the Virgin Islands: An Eighty-year Reassessment of the Islands' Natural History by Julio C. Figueroa Colón. Isis: A Journal of the History of Science Society 88: 357.

Box, H. E., 1925. Porto Rican cane-grubs and their natural enemies, with suggestions for the control of lamellicorn larvae by means of wasp-parasites (Scoliidae). J. Dept. Agric. P.R. 9: 291-356.

Bridwell, J. C., 1943. A new Amblycerus affecting seeds of Prosopis chilensis in Puerto Rico and Hispaniola. J. Agric. Univ. P.R. 27: 133-135.

Bryant, E. B., 1942. Additions to the spider fauna of Puerto Rico. J. Agric. Univ. P.R. 26: 1-19.

Cabrera-Asencio, I., 2001. Liriomyza trifolii (Burgess) (Diptera: Agromyzidae) un nuevo récord y un nuevo reporte en cebolla, Allium cepa L., para Puerto Rico. J. Agric. Univ. P.R. 85: 83-84.

Cabrera-Asencio, I., 1998. Dolichothrips indicus (Hood) (Thysanoptera: Phlaeothripidae): Un nuevo reporte para pimiento y berenjena en Puerto Rico. J. Agric. Univ. P.R. 82: 111-112.

Cabrera-Asencio, I., 1996. Nuevos reportes de barrenadores: Apate monacha (F.) (Coleoptera: Bostrichidae), Hypothenemus sp. e Hypocryphalus mangiferae (H.) (Coleop- 
tera: Scolytidae) del mangó (Mangifera indica) en Puerto Rico. J. Agric. Univ. P.R. 80: $87-88$.

Cabrera-Asencio, I., A. Ramírez, S. Cruz, L. Vélez, L. Sáez and A. E. Segarra-Carmona, 2008. Holopothrips tabebuia SP.N. Cabrera \& Segarra (Thysanoptera: Phlaeothripidae) en los robles Tabebuia heterophylla y Tabebuia aurea en Puerto Rico. J. Agric. Univ. P.R. 92: 225-229.

Cabrera-Asencio, I., L. I. Rivera-Vargas and A. L. Vélez, 2009. First report of mango blossom midge Gephyraulus mangiferae (Felt) (Diptera: Cecidomyiidae) in Puerto Rico. J. Agric. Univ. P.R. 93: 255-257.

Cabrera-Asencio, I., J. A. Santiago-Blay and A. L. Vélez, 2003. Epitragus aurulentus (Kirsch) (Coleoptera: Tenebrionidae): A new record and report for Puerto Rico. $J$. Agric. Univ. P.R. 87: 161-164.

Cabrera-Asencio, I. and A. Vélez, 2011. Clinodiplosis capsici (Diptera: Cecidomyiidae): Una nueva plaga para los ajíes y pimientos (Capsicum sp.: Solanaceae) en Puerto Rico. J. Agric. Univ. P.R. 95: 85-87.

Cabrera-Asencio, I. and A. L. Vélez, 2009. Androthrips ramachandrai Karny (Thysanoptera: Phlaeothripidae): Un nuevo récord para Puerto Rico. J. Agric. Univ. P.R. 93: 259-261.

Caldwell, J. S., 1947. The Synonym of Empoasca fabalis De Long Cicadellidae: (Homoptera). J. Agric. Univ. P.R. 31: 226.

Caldwell, J. S., 1942. New Psyllidae from Puerto Rico with notes on others (Homoptera). J. Agric. Univ. P.R. 26: 28-33.

Caldwell, J. S. and L. F. Martorell, 1951. New leafhoppers from Puerto Rico (Cicadellidae: Homoptera). J. Agric. Univ. P.R. 35: 88-89.

Caldwell, J. S. and L. F. Martorell, 1951. A brief review of the Psyllidae of Puerto Rico (Homoptera). Ann. Ent. Soc. Am. 44: 603-613.

Caldwell, J. S. and L. F. Martorell, 1950. Review of the Auchenorrhynchous Homoptera of Puerto Rico. Part I. Cicadellidae. J. Agric. Univ. P.R. 34: 1-132.

Caldwell, J. S. and L. F. Martorell, 1950. Review of the Auchenorrhynchous Homoptera of Puerto Rico. Part II. The Fulgoroidea except Kinnaridae. J. Agric. Univ. P.R. 34: 133-269.

Carpintero, D. J. and J. Maldonado-Capriles, 1996. Diagnostic characters and key to the genera of American Ectrichodiinae (Heteroptera, Reduviidae). Carib. J. Sci. 32: 125-141.

Carpintero, D. J. and J. Maldonado-Capriles, 1991. Contributions to the knowledge of American Ectrichodiinae. III. The genus Cricetopareis Breddin, 1903 (Hemiptera: Reduviidae). J. Agric. Univ. P.R. 75: 81-86.

Carpintero, D. J. and J. Maldonado-Capriles, 1990. Contributions to the knowledge of American Ectrichodiinae. II. Notes about Rhiginia and Pothea (Hemiptera: Reduviidae). J. Agric. Univ. P.R. 74: 449-456.

Carpintero, D. J. and J. Maldonado-Capriles, 1988. Contributions to the knowledge of American Ectrichodiinae I. Notes about Rhiginia (Hemiptera: Reduviidae). J. Agric. Univ. P. R. 72: 251-254.

Carvalho, J. C. M. and J. Maldonado-Capriles, 1982. Neotropical Miridae. CCXXVIII: Genus Lundiella Carvalho with descriptions of new species (Hemiptera). Rev. Bras. Biol. 42: 55-61.

Chapin, E. A., 1935. New species of Scarabaeidae (Coleoptera) from Puerto Rico and the Virgin Islands. J. Agric. Univ. P.R. 19:67-71.

Colón-Ferrer, M. and S. Medina-Gaud, 1999. Contribution to the Systematic of Diaspidids (Homoptera: Diaspididae) of Puerto Rico. University Puerto Rico Mayagüez Campus, Agricultural Experiment Station Department of Crop Protection, Río Piedras, Puerto Rico. $258 \mathrm{pp}$.

Comstock, W. P., 1944. Insects of Porto Rico and the Virgin Islands: Rhopalocera or Butterflies. In: Scientific Survey of Porto Rico and the Virgin Islands. Vol 12, Pt 4. New York: New York Academy of Sciences. pp 421-622.

Correa-Galíndez, E., A. Armstrong, C. Cruz and E. Abreu, 2003. New records of natural enemies of the pepper weevil, Anthonomus eugenii Cano (Coleoptera: Curculionidae), in Puerto Rico. J. Agric. Univ. P.R. 87: 69-72. 
Coscaron, M. C. and J. Maldonado-Capriles, 1988. Contribution to the knowledge of Rasahus Amyot and Serville, 1843 (Hemiptera: Reduviidae); description of a new species. J. Agric. Univ. P.R. 72: 247-250.

Cotte, O., 1989. Oxidia vesulia (Cramer) (Lepidoptera: Geometridae), a geometrid caterpillar of coffee in Puerto Rico. J. Agric. Univ. P.R. 73: 159-160.

Cotte, O., 1989. Scutigerella inmaculata (Newport), the symphylid in pineapple fields of Puerto Rico. J. Agric. Univ. P.R. 73: 275-276.

Cotte, O. and C. Cruz, 1989. Natural enemies of leafhopper of the genus Empoasca (Homoptera:Cicadellidae) in pigeon peas. J. Agric. Univ. P.R. 73: 161-163.

Cotton, R. T., 1918. Insects attacking vegetables in Porto Rico. J. Dept. Agric. Labor P.R. 2: 265-317.

Cotton, R. T., 1917. The eggplant lace-bug in Puerto Rico. J. Board Commissioners P.R. 1: $168-170$.

Curran, C. H., 1928. Insects of Porto Rico and the Virgin Islands. Diptera or two-winged flies. In: Scientific Survey of Porto Rico and the Virgin Islands. Vol 11, Pt 1. New York: New York Academy of Sciences. 118 pp.

DeLong, D. M., 1932. Three species of Empoasca leafhoppers known to affect economic plants in Haiti (including the description of two new species). J. Dept. Agric. Labor P.R. 16: 113-115.

Denmark, H. A. and M. H. Muma, 1975. The Phytoseiidae (Acarina: Mesostigmata) of Puerto Rico. J. Agric. Univ. P.R. 59: 279-304.

Dozier, H. L., 1937. Description of miscellaneous chalcidoid parasites from Puerto Rico (Hymenoptera). J. Agric. Univ. P.R. 21: 121-135.

Dozier, H. L., 1932. Descriptions of new Mymarid egg parasites from Haiti and Puerto Rico. J. Dept. Agric. Labor P.R. 16: 81-91.

Dozier, H. L., 1932. Notes on the Genus Aneristus Howard with description of a new species (Hymenoptera; Chalcidoidea). J. Dept. Agric. Labor P.R. 16: 93-102.

Dozier, H. L., 1932. Two important West Indian seed-infesting wasps. J. Dept. Agric. Labor P.R. 16: 103-112.

Dozier, H. L., 1926. Notes on Porto Rican Thysanoptera. J. Dept. Agric. Labor P.R. 10: 279-281.

Dozier, H. L., 1926. Notes on Porto Rico scale parasites. J. Dept. Agric. Labor P.R. 10: 267-277.

Dozier, H. L., 1926. Some new and interesting Porto Rican leafhoppers. J. Dept. Agric. Labor P.R. 10: 259-265.

Dozier, H. L., 1925. An outbreak of the red-striped sugar-cane scale. J. Dept. Agric. Labor P.R. 9: $357-367$.

Drake, C. J. and J. Maldonado-Capriles, 1955. New apterous Aradidae from Puerto Rico (Hemiptera). J. Wash. Acad. Sci. 45: 289-294.

Drake, C. J. and J. Maldonado-Capriles, 1954. Puerto Rican water-striders (Hemiptera). Proc. Biol. Soc. Wash. 67: 219-221.

Feliciano, M., I. Cabrera-Asencio and L. I. Rivera-Vargas, 2008. Frankliniella occidentalis, F. schultzei and F. fusca (Thysanoptera: Thripidae) in Puerto Rico. J. Agric. Univ. P.R. 92: 107-110.

Felt, E. P., 1932. A new citrus cambium miner from Puerto Rico. J. Dept. Agric. Labor P.R. 16: 117-118.

Figueroa-Colón, J. C. (ed), 1996. The Scientific Survey of Puerto Rico and the Virgin Islands. An Eighty-Year Reassessment of the Islands' Natural History. Vol 776. Annals of the New York Academy of Sciences. $273 \mathrm{pp}$.

Fisher, W. S., 1942. New Coleoptera from Puerto Rico. J. Agric. Univ. P.R. 25: 37-39.

Fisher, W. S., 1935. New cerambycid beetles from Puerto Rico. J. Agric. Univ. P.R. 19: 51-63.

Fisher, W. S., 1935. New eucnemid beetles from Puerto Rico. J. Agric. Univ. P.R. 19: 65-66.

Forbes, T. M., 1931. Supplementary report on the Heterocera or moths of Porto Rico. J. Dept. Agric. P.R. 15: 339-394.

Forbes, T. M., 1930. Insects of Porto Rico and the Virgin Islands. Heterocera or moths (excepting the Noctuidae, Geometridae and Pyralidae). In: Scientific Survey of 
Porto Rico and the Virgin Islands. Vol 12, Pt 1. New York: New York Academy of Sciences. $171 \mathrm{pp}$.

Forbes, W. T. M. and M. D. Leonard, 1930. A new leaf-miner of cotton in Porto Rico (Nepticula gossypii new species). J. Dept. Agric. Labor P.R. 14: 151-57.

Fox, I., 1977. The domestic cat, Felis catus L., a new host record for the tick Ornithodorus puertoricensis Fox. J. Agric. Univ. P.R. 61: 509.

Fox, I., 1957. The insect family Japygidae (Order Thysanura) in Puerto Rico. J. Agric. Univ. P.R. 41: 35-37.

Fox, I., 1955. A catalogue of the bloodsucking midges of the Americas (Culicoides, Leptoconops, and Lasiohelea) with keys to the subgenera and Neartic species, a geographic index, and bibliography. J. Agric. Univ. P.R. 39: 214-285.

Fox, I., 1942. The occurrence of a rare genus of ticks on bats in Puerto Rico (Acarina: Spelaeorhynchidae). J. Agric. Univ. P.R. 26: 95-97.

Fox, I. and D. de León, 1983. On the tropical horse tick and the southern cattle tick in Puerto Rico. J. Agric. Univ. P.R. 67:57-59.

Franqui, R. A. and S. Medina-Gaud, 2003. Identificación de Insectos de Posible Introducción a Puerto Rico. Information booklet printed by: University of Puerto Rico, Mayagüez Campus, Agricultural Experiment Station, Río Piedras, Puerto Rico. 19 pp.

Franqui, R. A., S. Medina-Gaud and F. Gallardo-Covas, 1991. Xylosandrus compactus (Eichoff), Coleoptera: Scolytidae, the black twig borer attacking coffee in Puerto Rico. J. Agric. Univ. P.R. 75: 183-184.

Franqui, R. A., J. A. Santiago-Blay and S. Medina-Gaud, 1997. The "Museo de Entomología y Biodiversidad Tropical" of the Agricultural Experiment Station, University of Puerto Rico. Fla. Entomol. 80: 490-492.

Froeschner, R. C. and J. Maldonado-Capriles, 1992. A synopsis of burrowing bugs of Puerto Rico with description of new species (Melanaethus wolcotti) (Heteroptera: Cydnidae). J. Agric. Univ. P.R. 76: 177-185.

Gahan, A. B., 1943. A new encyrtid parasitic in the eggs of Hesperiidae. J. Agric. Univ. P.R. 27: 137-139.

Gallardo-Covas, F., 2005. Parasitoids of Pseudoplusia includens Walker (Lepidoptera: Noctuidae) larvae on the south coast of Puerto Rico. J. Agric. Univ. P.R. 89:119122.

Gallardo-Covas, F., 1988. Faunal survey of the coffee leafminer, Leucoptera coffeella, parasitoids in Puerto Rico. J. Agric. Univ. P.R. 72: 255-264.

Gallardo-Covas, F., 1987. Platypus ratzeburgi Chapuis (Coleoptera: Platypodidae): Anew pest attacking coffee. Res. Note. J. Agric. Univ. P.R. 71: 335-336.

García-Díaz, J., 1938. An ecological survey of the fresh water insects of Puerto Rico. I. The Odonata: With new life-histories. J. Agric. Univ. P.R. 22: 43-97.

García-Tudurí, J. C., S. Medina-Gaud and L. F. Martorell, 1974. Preliminary list of the insects of Desecheo Island, Puerto Rico. J. Agric. Univ. P.R. 58: 125-133.

Genaro, J. A. and N. M. Franz, 2008. The bees of Greater Puerto Rico (Hymenoptera: Apoidea: Anthophila). Insecta Mundi 40: 1-24.

Gordon-Mendoza, R., S. Medina-Gaud and A. Armstrong, 1991. Nuevo hospedero alterno del picudo del pimiento, Anthonomus eugenii Cano, en Puerto Rico. Res. Note. J. Agric. Univ. P.R. 75: 423.

Gurney, A. B. and J. Maldonado-Capriles, 1962. On the cricket Hygronemobices alleni (Morse), with special reference to a first record of the genus in Puerto Rico (Orthoptera, Gryllidae). Carib. J. Sci. 2: 156-158.

Homziak, N. T. and J. Homziak, 2006. Papilio demoleus (Lepidoptera: Papilionidae): A new record for the United States, Commonwealth of Puerto Rico. Fla. Entomol. 89: 485-488.

Johannsen, O. A., 1938. New species of Nemocera from Puerto Rico. J. Agric. Univ. P.R. 22: $219-225$.

Jones, T. H., 1917. A List of the Coccidae of Porto Rico. J. Board Commisioners Agric. P.R. 1: 1-16.

Jones, T. H., 1915. Aphids or plant-lice attacking sugar-cane in Puerto Rico. The Board of Commissioners of Agriculture. Bulletin 11. 19 pp. 
Jones, T. H., 1915. The moth stalk borer (Diatraea saccharalis Fabr.) of sugar cane. The Board of Commissioners of Agriculture. Bulletin 12. $31 \mathrm{pp}$.

Jones, T. H., 1915. The sugar-cane weevil root borer (Diaprepes spengleri L.). The Board of Commissioners of Agriculture. Bulletin $14.19 \mathrm{pp}$.

Jones, T. H. and G. N. Wolcott, 1922. The caterpillars which eat the leaves of sugar cane in Porto Rico. J. Dept. Agric. Labor P.R. 6: 38-50.

Klots, E. B., 1932. Insects of Porto Rico and the Virgin Islands: Odonata or dragon flies. In: Scientific Survey of Porto Rico and the Virgin Islands. Vol 14. New York: New York Academy of Sciences. $107 \mathrm{pp}$.

Krame, J. P. and L. F. Martorell, 1960. First records for the rice plant hopper, Sogata orizicola Muir, in Puerto Rico (Homoptera: Fulgoroidea: Delphacidae). J. Agric. Univ. P.R. 44: 163-165.

Kristsky, G. R., 1979. A revision of the genus Enicocephalus (Hemiptera: Enicocephalidae). Res. Note, J. Agric. Univ. P.R. 63: 91-99.

Leonard, M. D., 1958. A preliminary survey of the plant mites of Puerto Rico. J. Agric. Univ. P.R. 42: 39-144.

Leonard, M. D., 1932. The initiation of an insect pest survey in Porto Rico. J. Dept. Agric. Labor P.R. 16: 59-64.

Leonard, M. D., 1932. The pink bollworm of cotton in Porto Rico. J. Dept. Agric. Labor P.R. 16: 65-74.

Leonard, M. D., 1932. Additional references to the bean lace bug. J. Dept. Agric. Labor P.R. 16: 75-76.

Leonard, M. D., 1930. A little-known root-weevil of cassava (Coelosternus sulcatus Boheman). J. Dept. Agric. Labor P.R. 14: 159-165.

Leonard, M. D. and A. S. Mills, 1931. Observation on the bean lace bug in Porto Rico. $J$. Dept. Agric. Labor P.R. 15: 309-323.

Lingafelter, S. W. and C. J. Micheli, 2004. New species of cerambycidae (Coleoptera) from Puerto Rico with records and notes for other species. J. New York Entomol. Soc. 112: 37-55.

Maldonado-Capriles, J., 1996. The status of insect alpha taxonomy in Puerto Rico after the Scientific Survey, pp 201-216. In: J. C. Figueroa Colon (ed). The Scientific Survey of Puerto Rico and the Virgin Islands: An Eighty-Year Reassessment of the Islands' Natural History. Vol 776. Annals of the New York Academy of Sciences. 273 pp.

Maldonado-Capriles, J., 1996. New taxa and key to the tribes and genera in Tribelocephalinae Stal 1866 (Heteroptera: Reduviidae). Proc. Entomol. Soc. Wash. 98: 138144.

Maldonado-Capriles, J., 1995. A new Ctenotrachelus and notes about other species in the genus (Heteroptera: Reduviidae: Stenopodainae). Carib. J. Sci. 31: 141-147.

Maldonado-Capriles, J., 1995. Notes about Vescinae, a key to the world genera, and description of two new Chopardita (Heteroptera: Reduviidae). Proc. Entomol. Soc. Wash. 97: 626-633.

Maldonado-Capriles, J., 1994. Pnirontis grandis n. sp. (Heteroptera: Reduviidae: Stenopodainae). Proc. Entomol. Soc. Wash. 96: 713-716.

Maldonado-Capriles, J., 1994. A new species of Seridentus Osborn, 1904 and a key to the species (Heteroptera: Reduviidae: Stenopodainae). Proc. Entomol. Soc. Wash. 96: 717-722.

Maldonado-Capriles, J., 1993. A newly discovered homonym in Ectomocoris (Heteroptera: Reduviidae: Peiratinae). Proc. Entomol. Soc. Wash. 95: 128.

Maldonado-Capriles, J., 1993. A new species of Ghilianella and the female of Ghilianella claviventris (Bergroth) (Heteroptera: Reduviidae: Emesinae). Proc. Entomol. Soc. Wash. 95: 558- 561.

Maldonado-Capriles, J., 1993. Redescription of Nesocastolus nigricornis (Fracker and Bruner) and notes on the genus (Heteroptera: Reduviidae: Harpactorinae). Proc. Entomol. Soc. Wash. 95: 562-563.

Maldonado-Capriles, J., 1992. New host for Pseudopteromalus calandrae (Howard) (Hymenoptera: Pteromalidae) in Puerto Rico. J. Agric. Univ. P.R. 76: 209. 
Maldonado-Capriles, J., 1992. On a small collection of Reduviidae (Insecta: Heteroptera) from Brazil. J. Agric. Univ. P.R. 76: 9-14.

Maldonado-Capriles, J., 1991. Additions and corrections to "The Miridae of Puerto Rico" (Insecta: Heteroptera). Carib. J. Sci. 27: 117-123.

Maldonado-Capriles, J., 1990. Systematic Catalogue of the Reduviidae of the World. Special Publ. Carib. J. Sci. 704 pp.

Maldonado-Capriles, J., 1987. Orbella, a new harpactorine genus (Hemiptera: Reduviidae). J. Agric. Univ. P.R. 71: 193-198.

Maldonado-Capriles, J., 1987. Homolocaria punctatus n. sp. and key to the species in the genus (Reduviidae: Microtominae). J. Agric. Univ. P.R. 71: 249-254.

Maldonado-Capriles, J., 1987. New names in Veledella and Sastrapada. First description of male of Lamotteits ornatus Villiers (Reduviidae). J. Agric. Univ. P.R. 71: 199-202.

Maldonado-Capriles, J., 1987. Homalocoris punctatus n. sp. and key to the species in the genus (Reduviidae, Microtominae). J. Agric. Univ. P.R. 71: 249-253.

Maldonado-Capriles, J., 1986. Designation of lectotypes from New World reduviid syntypes in the "Institut royal des Sciences naturelles de Belgique" (Insecta: Hemiptera). Bull. Inst. R. Sci. Belg. Entomol. 56: 41-44.

Maldonado-Capriles, J., 1986. The genus Phicontis the subinermis group of species (Hemiptera: Reduviidae: Stenopodainae). J. Agric. Univ. P.R. 70(1): 9-18.

Maldonado-Capriles, J., 1986. The Reduviidae (Hemiptera) of Puerto Rico: An annotated list. J. Agric. Univ. P.R. 70: 1-7.

Maldonado-Capriles, J., 1986. Two new species of Apronius Stal with notes on the genus (Heteroptera: Reduviidae: Stenopodainae). J. New York Entomol. Soc. 94: 174-179.

Maldonado-Capriles, J., 1984. A new species of Eurychilella (Hemiptera: Miridae). J. Agric. Univ. P.R. 68: 75-78.

Maldonado-Capriles, J., 1984. The genus Ataenius (Coleoptera: Scarabaidae) in Puerto Rico. Res. Note. J. Agric. Univ. P.R. 68: 111- 112.

Maldonado-Capriles, J., 1984. The genus Knightonia Carvalho and Drake (Miridae: Hemiptera: Hyaliodini). J. Agric. Univ. P. R. 68: 307-310.

Maldonado-Capriles, J., 1983. Concerning new and old species of Heza (Hemiptera: Reduviidae). J. Agric. Univ. P.R. 67: 407-418.

Maldonado-Capriles, J., 1980. The genus Jobertus Distant, 1884 (Hemiptera: Miridae: Orthotylinae). J. Agric. Univ. P.R. 64: 304-309.

Maldonado-Capriles, J., 1977. Studies on Idiocerinae leafhoppers: XVII: Three new Neotropical genera (Homoptera: Cicadellidae). Proc. Ent. Soc. Wash. 79: 317-325.

Maldonado-Capriles, J., 1976. The genus Heza (Hemiptera: Reduviidae). J. Agric. Univ. P. R. 60: 403-433.

Maldonado-Capriles, J., 1976. Three new species of Castolus and a key to the species (Hemiptera: Reduviidae). Proc. Entomol. Soc. Wash. 78: 435- 446.

Maldonado-Capriles, J., 1975. Studies on Idiocerinae leafhoppers, XVI: Pachymetopius Matsumura transferred to Coelidiinae (Homoptera: Cicadellidae). Proc. Entomol. Soc. Wash. 77: 306-307.

Maldonado-Capriles, J., 1975. Two new Neotropical Stenolemus (Reduviidae: Emesinae). Proc. Entomol. Soc. Wash. 77: 456-459.

Maldonado-Capriles, J. 1974. The Neotropical genus Melanopleurus (Hemiptera: Lygaeidae). Proc. Entomol. Soc. Wash. 76: 22-30.

Maldonado-Capriles, J., 1974. Studies on Idiocerinae leafhoppers, XI. The Neotropical genus Chunroides (Cicadellidae). Entomol. Mon. Mag. 110: 233-236.

Maldonado-Capriles, J., 1973. Parapycnoderes, a new genus for Pycnoderes porrectus (Distant) (Hemiptera: Miridae). Proc. Entomol. Soc. Wash. 75: 314-317.

Maldonado-Capriles, J., 1973. Studies on Idiocerinae leafhoppers: X. Idioscopus nitidulus (Walker), new combination (Homoptera: Cicadellidae). Proc. Entomol. Soc. Wash. 75: 179-181.

Maldonado-Capriles, J., 1972. Neotropical Reduviidae (Heteroptera) in the Museum of Zoology of the University of Helsinki, Finland, with description of new species. Not. Entomol. 52: 47-56. 
Maldonado-Capriles, J., 1971. Platybasicomis ramosi, a new Neotropical genus and species (Hemiptera: Miridae: Hyaliodini). Proc. Entomol. Soc. Wash. 73: 142145.

Maldonado-Capriles, J., 1970. Descriptions of new species of the genus Termatophylidea with a key to the known species (Hemiptera: Miridae). Proc. Entomol. Soc. Wash. 72: 119-126.

Maldonado-Capriles, J., 1970. New species in the genus Sericophanes Reuter (Hemiptera: Miridae). Proc. Entomol. Soc. Wash. 72: 98-106.

Maldonado-Capriles, J., 1969. The Miridae of Puerto Rico (Hemiptera). Tech. Paper No. 45. Univ. Puerto Rico Agric. Exp. Stn. 133 pp.

Maldonado-Capriles, J., 1968. A new genus and species of Deltocephalinae from Puerto Rico (Homoptera:Cicadellidae). Proc. Entomol. Soc. Wash. 70: 35-37.

Maldonado-Capriles, J., 1968. Nuevos y viejos emesinos Neotropicales (Hemiptera, Reduviidae). Mem. Soc. Cienc. Nat. La Salle 28: 265-280.

Maldonado-Capriles, J., 1968. Studies in Idiocerinae leafhoppers: IV. A new species of Balocha and one of Pedioscopus, mimics. Proc. Entomol. Soc. Wash. 70: 97-100.

Maldonado-Capriles, J., 1966. A note on Zanchisme (Hemiptera: Miridae). Proc. Entomol. Soc. Wash. 68: 21-24.

Maldonado-Capriles, J., 1961. Studies on Idiocerinae leafhoppers: 1. idiocerinus Baker, 1915, synonym of Balocha Distant, 1908, and notes on the species of Balocha (Homoptera: Cicadellidae). Proc. Entomol. Soc. Wash. 63: 300-308.

Maldonado-Capriles, J., 1960. Assassin bugs of the genus Ghilianella in the Americas (Hemiptera, Reduviidae, Emesinae). Proc. U.S. Nat. Mus. 112: 393-450.

Maldonado-Capriles, J., 1954. A note on the genus Idiotettix Osborn (Homoptera, Cicadellidae). Proc. Entomol. Soc. Wash. 56: 247-250.

Maldonado-Capriles, J., 1953. Redescription of the genus Burtimus Stal and description of a new species from Puerto Rico (Hemiptera: Coreidae). Proc. Entomol. Soc. Wash. 55: $40-44$

Maldonado-Capriles, J., 1953. Five new Neotropical species of Ghilianella (Hemiptera, Reduviidae). Proc. Ent. Soc. Wash. 55: 189-195.

Maldonado-Capriles, J., 1948. A new Enicocephalus from Puerto Rico. Proc. Entomol. Soc. Wash. 50: 159-160.

Maldonado-Capriles, J., 1948. Three new Neotropical species of the reduviid genus Ploiaria Scopoli (Hemiptera). Proc. Entomol. Soc. Wash. 50: 18-22.

Maldonado-Capriles, J., 1945. The fleas of Puerto Rico. Puerto Rico J. Public Health Trop. Med. 21: 73-183. [also in Spanish, 21: 184-192]

Maldonado-Capriles, J., E. Abreu, C. Negrón and D. Rodríguez, 1991. Presencia del ácaro Tyrophagus putrescientae (Schrank) (Acarina: Acaridae) sobre un cadáver embalsamado. Science-Ciencia (Ponce, PR) 17: 62-63.

Maldonado-Capriles, J. and A. Berríos, 1977. The immature stages of Copestylum vacuum (F) (Diptera: Syrphidae), a new record for Puerto Rico. J. Agric. Univ. P. R. 56: 395-398.

Maldonado-Capriles, J. and D. J. Carpintero, 1993. Redescription of the harpactorine genus Sosius Champion 1899, with the description of a new species (Heteroptera: Reduviidae). Proc. Entomol. Soc. Wash. 95: 223-227.

Maldonado-Capriles, J. and T. H. Farr, 1962. On some Jamaican Triatominae and Emesinae (Reduviidae: Hemiptera). Proc. Entomol. Soc. Wash. 64: 187-194.

Maldonado-Capriles, J. and P. W. Lozada-Robles, 1992. Key to the group of Neotropical wasp-mimetic harpactorine genera and the description of a new species (Hemiptera: Reduviidae). Proc. Entomol. Soc. Wash. 94: 162-165.

Maldonado-Capriles, J. and S. Medina-Gaud, 1985. Insectos dañinos y beneficiosos de Puerto Rico. (Manual de Laboratorio). Librería Universal, Inc., Mayagüez, PR. 200 pp.

Maldonado-Capriles, J. and S. Medina-Gaud, 1977. The ticks in Puerto Rico (Arachnida: Acarina). J. Agric. Univ. P. R. 61: 402-404.

Maldonado-Capriles, J. and S. Medina-Gaud, 1971. Distribution and abundance of the cattle tail louse, Haematopinus quadripertusus Fahr. (Anoplura, Haematopinidae) in Puerto Rico. J. Agric. Univ. P.R. 55: 516-517. 
Maldonado-Capriles, J. and J. Miró-Mercado, 1978. The wing louse, Lipeurus caponis (L.) (Mallophaga: Philopteridae) attacking poultry in Puerto Rico. J. Agric. Univ. P.R. 62(3): 309-310.

Maldonado-Capriles, J. and M. Miró-Mercado, 1977. The mite Ornithonyssus sylviarum (C. and F) (Arachnida: Acarina: Macronyssidae) attacking fowl in Puerto Rico. J. Agric. Univ. P. R. 61 (3): 400-401.

Maldonado-Capriles, J. and C. A. Navarro, 1967. Additions and corrections to Wolcott's "Insects of Puerto Rico." Carib. J. Sci. 7: 45-64.

Maldonado-Capriles, J. and C. A. Navarro, 1962. Number of insect species reported from Puerto Rico. Carib. J. Sci. 2: 22-26.

Maldonado-Capriles, J. and A. Ortiz, 1978. The allotype of Arenasella maldonadoi and change of depository for two of Fennah's holotypes (Homoptera: Tropiduchidae and Issidae). Proc. Entomol. Soc. Wash. 80: 380-382.

Maldonado-Capriles, J., W. F. Pippin and M. L. Kuns, 1958. An annotated checklist of the mosquitoes of Mona Island, Puerto Rico, and the larva and male of Aedes obturbator D. \& K. (Diptera, Culicidae). Proc. Entomol. Soc. Wash. 60:65-68.

Maldonado-Capriles, J., J. A. Santiago Blay and G. O. Jr. Poinar, 1993. Paleoploiariola venosa, A new fossil Emesinae (Heteroptera: Reduviidae) genus and species from Dominica amber. J. Agric. Univ. P.R. 77: 95-100.

Maldonado-Capriles, J. and J. A. Santiago-Blay, 1992. A new species of the Neotropical genus Sphaeridops Amyot \& Serville, 1843 (Sphaeridopinae: Reduviidae). Proc. Entomol. Soc. Wash. 94: 508-511.

Maldonado-Capriles, J. and J. A. Santiago-Blay, 1991. Classification of Homalocoris (Heteroptera: Reduviidae: Hammacerinae), with the description of a new species. Proc. Entomol. Soc. Wash. 93: 703-708.

Mari-Mutt, J. A., 1996. Supplement to the catalog of the Neotropical Collembola: August 1989 to April 1996. Carib. J. Sci. 32: 166-175.

Mari-Mutt, J. A., 1988. Two new species of Lepidocyrtus from Puerto Rico and descriptive notes for $L$. ramose Mari Mutt (Collembola:Entomobryidae). Carib. J. Sci. 24: 197-200.

Mari-Mutt, J.A., 1987. Redescription of Seira oceanica Yosii, 1960 (Collembola: Entomobryidae). J. Agric. Univ. P.R. 71: 331-333.

Mari-Mutt, J. A., 1987. Puerto Rican species of Paronellidae (Insecta: Collembola). Carib. J. Sci. 23: 400-416.

Mari-Mutt, J. A., 1986. Comments on the taxonomic status of Strongylonotus Mac Gillirvray (Collembola: Entomobryidae). Carib. J. Sci. 22: 215-218.

Mari-Mutt, J.A., 1987. Redescription of Seira oceanica Yosii, 1960 (Collembola: Entomobryidae). J. Agric. Univ. P.R. 71: 331-334.

Mari-Mutt, J. A., 1986. Puerto Rican species of Seira (Collembola: Entomobryidae). Carib. J. Sci. 22: 145-158.

Mari-Mutt, J. A., 1986. Puerto Rican species of Lepidocyrtus and Pseudosinella (Collembola: Entomobryidae). Carib. J. Sci. 22: 1-40.

Mari-Mutt, J. A., 1986. Contribución al conocimiento de tres especies de Orchesellinae descritas por F. Bonet y redescripción de Orchesellides sinensis (Denis) (Collembola). EOS 61: 189-198.

Mari-Mutt, J.A., 1986. Collembola associated with grasses in the grounds of the University of Puerto Rico at Mayagüez. J. Agric. Univ. P.R. 70: 75-78.

Mari-Mutt, J. A., 1985. Two new species of Dicranocentrus from Puerto Rico and the Dominican Republic (Collembola: Entomobryidae). Carib. J. Sci. 21: 105-110.

Mari-Mutt, J. A., 1985. A new species of Heteromurus from Puerto Rico (Collembola: Entomobryidae). Entomol. News 96: 145-147.

Mari-Mutt, J. A., 1985. Eight new species of Dicranocentrus and redescriptions for $D$. thiacus and D. pilosus (Collembola: Entomobryidae: Orchesellinae). J. Agric. Univ. P.R. 69: 297-322.

Mari-Mutt, J. A., 1985. Three new species of Heteromurus (Alloscopus) and descriptive notes for species of the subgenus (Collembola: Entomobryidae). Fla. Entomol, 68: 335-346. 
Mari-Mutt, J.A., 1984. New records for Corynothrix borealis and a study of its variability (Collembola: Entomobryidae: Orchesellinae). Int. J. Entomol. 26: 369-377.

Mari-Mutt, J. A., 1984. Una nueva especie de Oncopodura de Puerto Rico (Collembola: Oncopoduridae). Carib. J. Sci. 20: 163-167.

Mari-Mutt, J. A., 1982. Observaciones preliminares sobre la distribución geográfica de los colémbolos de Puerto Rico (Insecta). Carib. J. Sci. 18: 29-34.

Mari-Mutt, J. A., 1981. Redescription of Willowsia jacobsoni (Borner) an entomobryid with conspicuous sexual dimorphism (Insecta: Collembola). J. Agric. Univ. P.R. 65: 361-373.

Mari-Mutt, J. A., 1981. New genus, a new species and complements to the descriptions of seven Neotropical Dicranocentrus (Collembola:Entomobryidae: Orchesellinae). J. Agric. Univ. P.R. 65 (2): 90-107.

Mari-Mutt, J. A., 1980. On the taxonomic status of Strongylonotus MacGillivray and Heteromuricus Imms (Collembola: Entomobryidae). Rev. Ecol. Biol. Sol. 16: 541-546.

Mari-Mutt, J. A., 1980. Descriptive notes for nine species of Heteromurus (s.g. Heteromurtrella) and a key to the species (Collembola: Entomobryidae). Pan-Pac. Entomol. 56: 11-25.

Mari-Mutt, J. A., 1980. A classification of the Orchesellinae with a key to the tribes, genera and subgenera (Collembola: Entomobryidae). Ann. Entomol. Soc. Am. 73: 455-459.

Mari-Mutt, J. A., 1980. A new tribe for Corynothrix borealis Tullberg 1876 and complements to its description (Collembola: Entomobryidae: Orchesellinae). Proc. Entomol. Soc. Wash. 82: 675-680.

Mari-Mutt, J. A., 1980. A revision of Heteromurus s. str. (Insecta: Collembola: Entomobryidae). Trans. Ill. State Acad. Sci. 72: 29-50.

Mari-Mutt, J. A., 1979. A review of the genus Uchidanura with description of a new species (Collembola: Neanuridae). Pac. Ins. 20: 53-58.

Mari-Mutt, J. A., 1979. A revision of the genus Dicranocentrus Schött (Insecta Collembola: Entomobryidae). Agr. Exp. Stn. Univ. P. R. Bull. 259, 79 pp.

Mari-Mutt, J. A., 1979. Heteromurtrella, a new tropical subgenus of Heteromurus with descriptions of two new species (Insecta: Collembola: Entomobryidae). J. Agric. Univ. P. R. 63: 214-222.

Mari-Mutt, J. A., 1978. A review of the genus Mastigoceras with remarks on its systematic position (Collembola: Entomobryidae). Pan-Pac. Entomol. 54: 43-47.

Mari-Mutt, J.A., 1978. A new Bovicomia from St. Thomas and Tortola (U.S. and British Virgin Islands), and notes on Bovicornia uniformis (Insecta: Collembola: Sminthuridae). J. Agric. Univ. P.R. 62: 165-170.

Mari-Mutt, J. A., 1978. The types of Collembola (Insecta) at the Illinois Natural History Survey. Ill. Nat. Hist. Surv. Biol. Notes, 103. 7 pp.

Mari-Mutt, J. A., 1978. The taxonomic status of Alloscopus and redescriptions of its two species (Collembola: Entomobryidae). Pan-Pacif. Entomol. 53: 241-249.

Mari-Mutt, J. A., 1977. Nine new records of Collembola (Insecta) from Puerto Rico and the first record of the order from Tortola, British West Indies. J. Agric. Univ. P.R. 61: 405-408.

Mari-Mutt, J. A., 1977. The taxonomic status of Portachorutes Wray (Collembola: Neanuridae). Proc. Entomol. Soc. Wash. 79: 10.

Mari-Mutt, J. A., 1976. The Genera of Collembola (Insecta) in Puerto Rico: Keys, Diagnoses, and General Comments. J. Agric. Univ. P.R. 60: 113-128.

Mari-Mutt, J. A. and M. M. Gruia, 1983. A revision of the genus Metasinella denis (Collembola: Entomobryidae). J. Agric. Univ. P.R. 67: 121-147.

Mari-Mutt, J. A. and F. Soto-Adames, 1987. Molting, fecundity and longevity in Willowsia jacobsoni (Collembola: Entomobryidae). Carib. J. Sci. 23: 298-304.

Martínez, N. J., A. Acosta and N. M. Franz, 2009. Structure of the beetle fauna (Insecta: Coleoptera) in forest remnants of western Puerto Rico. J. Agric. Univ. P.R. 93: 83-100.

Martorell, L. F., 1976. Annotated Food Plant Catalog of the Insects of Puerto Rico. University of Puerto Rico, Agricultural Experiment Station, Río Piedras, Puerto Rico. $303 \mathrm{pp}$. 
Martorell, L. F., 1973. The insects of Mona Island, Puerto Rico. In: Isla de Mona- Volumen II: Junta de Calidad Ambiental. J1-7 pp.

Martorell, L. F., 1973. Glyptotermes liberatus (Snyder) - (Isoptera: Kalotermitidae): A new termite record for Puerto Rico. J. Agric. Univ. P.R. 57: 355-356.

Martorell, L. F., 1959. Preliminary report on orchid pests in Puerto Rico. The Orchid Soc. P.R., Ann. Prog. pp 19-27.

Martorell, L. F., 1959. Preliminary report on orchid pests in Puerto Rico. Agric. Exp. Sta., Univ. P.R., Misc. Pub. 25

Martorell, L. F., 1955. Acanthochila spinacosta Van Duzee, A new Tingitid for Puerto Rico. J. Agric. Univ. P.R. 39: 47-48.

Martorell, L. F. and J. Adsuar, 1952. Insects associated with papaya virus diseases in the Antilles and Florida. J. Agric. Univ. P.R. 36: 319-329. [Also in J. Econ. Entomol. 45: 861-869].

Martorell, L. F., 1945. A survey of the forest insects of Puerto Rico. Part I \& II. J. Agric. Univ. P.R. 29: 69-608.

Martorell, L. F., 1943. Forests and forest entomology. Caribb. For. 4:132-134.

Martorell, L. F., 1941. Some notes on forest entomology IV. Caribb. For. 2: 80-83.

Martorell, L. F., 1940. Some notes on forest entomology. Caribb. For. 1: 31-32.

Martorell, L. F., 1940. Some notes on forest entomology. Caribb. For. 1: 23-24.

Martorell, L. F., 1939. Some notes on forest entomology. Caribb. For. 1: 25-26.

Martorell, L. F. and J. C. García-Tudurí, 1973. Notes on the accidental introduction of Umbonia cassicornis (Amyot \& Seville - (Hemiptera: Membracidae) into Puerto Rico and its control. J. Agric. Univ. P.R. 57: 307-313.

Martorell, L. F. and S. Medina-Gaud, 1974. Orchid pests in Puerto Rico. J. Agric. Univ. P.R. 58: 105-124.

Martorell, L. F. and G. N. Wolcott, 1939. Forest tree insects. Ann. Rept., Agric. Exp. Sta., Río Píedras, PR. 1937-38. p 44.

Mc Atee, W. L., 1932. A new Neotropical genus of Eupterygina (Homoptera) from Puerto Rico. J. Dept. Agric. Labor P.R. 16: 119-120.

Mc Gregor, E. A., 1943. A new spinning mite attacking sugarcane in Puerto Rico. J. Agric. Univ. P.R. 26: 91-94.

Medina-Gaud, S., 2006. The Muscidae (Insecta: Diptera) of Puerto Rico. University of Puerto Rico, Mayagüez Campus, Agricultural Experiment Station, Department of Crop Protection. XXI, 224 pp.

Medina-Gaud, S., 1978. The Muscidae of Puerto Rico. Retrospective Thesis and Dissertation. Paper 6574. 386 pp.

Medina-Gaud, S., 1977. Manual de Procedimientos para Colectar, Preservar y Montar Insectos y otros Artrópodos. Universidad de Puerto Rico, Recinto de Mayagüez, Colegio de Ciencias Agrícolas, Estación Experimental Agrícola. Boletín 254. 3-24.

Medina-Gaud, S., 1971. Thrips (Insecta: Thysanoptera) from Vieques Island (Puerto Rico). J. Agric. Univ. P.R. 55: 271-273.

Medina-Gaud, S., 1964. A new genus and two species of insects new for Puerto Rico. Res. Note, J. Agric. Univ. P.R. 48:67.

Medina-Gaud, S., 1964. Two new mites reported for Puerto Rico. J. Agric. Univ. P.R. 48: $67-68$.

Medina-Gaud, S., 1963. A new species of Heterothrips (Thysanoptera: Heterothripidae) from Puerto Rico. J. Agric. Univ. P.R. 47: 164-168.

Medina-Gaud, S., 1963. Leptopharsa constricta (Champion) a new lacewing bug (Tingidae: Hemiptera) for Puerto Rico. J. Agric. Univ. P.R. 47: 56-57.

Medina-Gaud, S., 1961. The Thysanoptera of Puerto Rico. University of Puerto Rico Agricultural Experiment Station. Technical Paper 32: 1-159.

Medina-Gaud, S., E. Abreu and R. A. Franqui, 1991. New thrips records (Insecta:Thysanoptera) from Puerto Rico. J. Agric. Univ. P.R. 75: 311-312.

Medina-Gaud, S., E. Abreu, F. Gallardo and R. A. Franqui, 1989. Natural enemies of the melonworm Diaphania hyalinata (L.) (Lepidoptera: Pyralidae) in Puerto Rico. $J$. Agric. Univ. P.R. 73: 313-320. 
Medina-Gaud, S. and E. Abreu, 1986. The coconut palm-eriophyid mite, Eriophyes guerreromis (Keifer), in Puerto Rico (Acarina: Eriophyidae). Res. Note, J. Agric. Univ. P.R. 70: 223-224

Medina-Gaud, S., F. Bennett, R. A. Franqui and A. Segarra-Carmona, 1994. New records of and notes on, insects (Insecta) from Puerto Rico. J. Agric. Univ. P. R. 78: 181-186.

Medina-Gaud, S., F. D. Bennett, A. Segarra-Carmona and A. Pantoja, 1989. Notes on insect pests of soursop (guanábana) Annona muricata L., and their natural enemies in Puerto Rico. J. Agric. Univ. P. R. 73: 383-390.

Medina-Gaud, S., F. D. Bennett and R. A. Franqui, 1991. La mosca negra de los cítricos, Aleurocanthus woglumi Ashby (Homoptera: Aleyrodidae), en Puerto Rico. J. Agric. Univ. P.R. 75: 301-305.

Medina-Gaud, S. and R. A. Franqui, 2001. Retithrips syriacus (Mayet), The Black vine thrips (Insecta: Thysanoptera: Thripidae) new to Puerto Rico. J. Agric. Univ. P.R. 85: 85-89.

Medina-Gaud, S., F. Gallardo-Covas, E. Abreu and R. Inglés. 1987. The insect of nispero (Manikara zapotae (L.) P. van Rogen) in Puerto Rico. Res. Note. J. Agric. Univ. P.R. 71: 129-132.

Medina-Gaud, S. and J. C. García-Tudurí, 1977. New arthropod records for Puerto Rico. Res. Note. J. Agric. Univ. P. R. 61: 409-412.

Medina-Gaud, S. and L. F. Martorell, 1974. The Insects of Caja de Muertos Island, Puerto Rico. J. Agric. Univ. P.R. 58: 244-272.

Medina-Gaud, S. and L. F. Martorell, 1973. New insect records for Puerto Rico. J. Agric. Univ. P.R. 57: 247-254.

Medina-Gaud, S., L. F. Martorell and N. Díaz-Acin, 1987. Los comejenes de importancia económica en Puerto Rico. Univ. P.R. Esta. Exp. Agric., Río Piedras. Bol. 280: $1-28$.

Medina-Gaud, S., L. F. Martorell and J. Maldonado-Capriles, 2003. Catálogo de los Nombres Comunes de Insectos y Acarinos de Importancia Económica en Puerto Rico. Universidad de Puerto Rico, Recinto de Mayagüez, Colegio de Ciencias Agrícolas, Estación Experimental Agrícola, Río Piedras, Puerto Rico. 149 pp.

Medina-Gaud, S., A. Rodríguez, J. Bird, M. Sosa and J. Escudero, 1989. Fulmekiola serrata (Kobus) (Thysanoptera: Thripidae): A new sugarcane pest in Puerto Rico. $J$. Agric. Univ. P.R. 73: 391-393.

Medina-Gaud, S., A. E. Segarra-Carmona and R. A. Franqui. 1991. The avocado lacewing bug, Pseudocysta perseae (Heidemann) (Hemiptera: Tingidae), in Puerto Rico. J. Agric. Univ. P.R. 75: 185-188.

Medina-Gaud, S., A. Segarra-Carmona and R. A. Franqui, 1991. New records of and notes on whiteflies (Homoptera: Aleyrodidae) from Puerto Rico. J. Agric. Univ. P.R. 75: 297-300.

Medina-Gaud, S., A. E. Segarra-Carmona and R. A. Franqui, 1991. Aleurocanthus woglumi Ashby (Homoptera: Aleyrodidae), the citrus blackfly, in Puerto Rico. J. Agric. Univ. P.R. 75: 301-305.

Micheli, J. A., 2010. Longicornios de Puerto Rico (Coleoptera: Cerambycidae). Pensoft Publisher, Sofia. 226 pp. 72 plates.

Micheli, J. A., 1978. Ten new insect records from Puerto Rico (Coleoptera). J. Agric. Univ. P.R. 62: 301-303.

Micheli, J.A. and C. J. Micheli, 2004. Five Puerto Rican longhorn beetles and other notes on West Indian acanthocinini (Coleoptera: Cerambycidae: Lamiinae). J. New York Entomol. Soc. 112: 18-36.

More, J. D., 1921. Las pulgas del tabaco. The Department of Agriculture and Labor. Circular $50.8 \mathrm{pp}$.

Moyá-Quintana, J. and I. Fox, 1970. Alphitobius laevigatus, a pest in Puerto Rico (Coleoptera: Tenebrionidae). J. Agric. Univ. P.R. 54: 181-183.

Moyá-Quintana, J. and I. Fox, 1970. Two coleopterous pests of pet food in Puerto Rico (Families Cucujidae and Tenebrionidae). J. Agric. Univ. P.R. 54: 413-415.

Muma, M. H. and M. L. Nazario, 1971. New Solpugids (Arachnida: Solpugidae) from Puerto Rico. J. Agric. Univ. P. R. 55: 506-512. 
Needham, J. G., 1941. Life history notes on some West Indian Coenagrionine dragonflies (Odonata). J. Agric. Univ. P.R. 25: 1-18.

Nosek, J., 1978. Protura: A new insect order record for Puerto Rico with description of new species. J. Agric. Univ. P.R. 62: 133-138.

O'Farrill-Nieves, H., 2008. Las plagas de las estructuras: identificación y control. Universidad de Puerto Rico, Colegio de Ciencias de Agrícolas, Servicio de Extensión Agrícola. 48 pp.

O'Farrill-Nieves, H., 2007. Las plagas comunes de los árboles urbanos de Puerto Rico: Identificación y Manejo Integrado. Universidad de Puerto Rico, Colegio de Ciencias Agrícolas,, Servicio de Extensión Agrícola. 56 pp.

O'Farrill-Nieves, H., 2007. Las plagas comunes del césped de los campos de golf de Puerto Rico: identificación y manejo integrado. Universidad de Puerto Rico, Colegio de Ciencias Agrícolas, Servicio de Extensión Agrícola. 122 pp.

O'Farrill, H. and S. Medina, 2007. Las plagas comunes del jardín: identificación y manejo integrado. Universidad de Puerto Rico, Colegio de Ciencias Agrícolas, Servicio de Extensión Agrícola. 109 pp.

Oman, P. W., 1937. New Eupterygine Leafhoppers from Puerto Rico (Homoptera - Cicadellidae). J. Agric. Univ. P.R. 21: 567-571.

Osborn, C. H., 1935. Insects of Porto Rico and the Virgin Islands: Homoptera (excepting the Sternorhynchi). In: Scientific Survey of Porto Rico and the Virgin Islands. Vol 14, Pt 2. New York: New York Academy of Sciences. pp 111-260.

Osborn, H., 1929. Notes on Porto Rican Homoptera. J. Dept. Agric. Labor P.R. 13: 81112.

Pantoja, A., J. Peña, W. Robles, E. Abreu, S. Halbert, M. de L. Lugo, E. Hernández and J. Ortiz, 2006. Aphids associated with papaya plants in Puerto Rico and Florida. J. Agric. Univ. P.R. 90: 99-107.

Pantoja, A., R. A. Franqui and S. Medina-Gaud, 1989. Homoptera Auchenorrhyncha from rice fields in Puerto Rico. J. Agric. Univ. P.R. 73: 395-396.

Pantoja, A., R. A Franqui and S. Medina-Gaud, 1989. Natural enemies and alternate hosts of Masramia trapezalis (Guenée) affecting rice in Puerto Rico J. Agric. Univ. P.R. 73: 397-398.

Pantoja, A., R. A. Franqui and S. Medina-Gaud, 1989. Homoptera Auchenorrhyncha from rice fields in Puerto Rico. J. Agric. Univ. P.R. 73: 395-396

Pantoja, A. and S. Medina-Gaud, 1988. Lissorhoptrus isthmicus Kuschel (Coleoptera: Curculionidae) a new rice pest for Puerto Rico. J. Agric. Univ. P.R. 72: 333.

Pantoja, A., A. Segarra, H. Ruiz and S. Medina-Gaud, 1988. Thrips palmi (Thysanoptera: Thripidae), a new insect pest for Puerto Rico. J. Agric. Univ. P.R. 72: 327-329.

Pantoja, J., F. Gallardo, D. Rivera, L. Wiscovitch and J. Peña, 1996. Minador de los cítricos: Phyllocnistis citrella Stainton, en Puerto Rico. J. Agric. Univ. P.R. 80: 85-86.

Pérez-Pérez, R., 1973. Liriomyza munda Frick (Diptera: Agromyzidae) attacking beans and cucumbers in Puerto Rico. J. Agric. Univ. P.R. 57(4): 350.

Ramos, J. A., 1957. Review of the Auchenorrhynchous Homoptera of Puerto Rico. J. Agric. Univ. P.R. 41: 38-117.

Ramos, J. A., 1946. The Insects of Mona Island (West Indies). J. Agric. Univ. P.R. 30(1): 1-74.

Ramos, S. J., 1982. Checklist of the butterflies of Puerto Rico (Lepidoptera, Rhopalocera, West Indies). Carib. J. Sci. 17: 59-68.

Romero, J. I. and R. F. Ruppel, 1973. A new species of Silba (Diptera, Lonchaeidae) from Puerto Rico. J. Agric. Univ. P.R. 57: 165-168.

Santiago-Blay, J. A. and J. Maldonado-Capriles, 1988. Observations on the true bugs Emesa tenerrima, a possible spider mimic, and Ghilianella borincana (Hemiptera: Reduviidae: Emesinae) from Puerto Rico. Proc. Entomol. Soc. Wash. 90: 369-372.

Santiago-Blay, J. A. and S. Medina-Gaud, 1986. Notes on the biology of Aspisoma ignitum (L): A new firefly for Puerto Rico. Fla. Entomol. 69: 440-444.

Schaus, W., 1940. Insects of Porto Rico and the Virgin Islands: Moths of the family Noctuidae. In: Scientific Survey of Porto Rico and the Virgin Islands. Vol 12, Pt 2. New York: New York Academy of Sciences. pp 177-290. 
Schaus, W., 1940. Insects of Porto Rico and the Virgin Islands: Moths of the family Geometridae and Pyralidae. In: Scientific Survey of Porto Rico and the Virgin Islands. Vol 12, Pt 3. New York: New York Academy of Sciences. pp 291-417.

Segarra-Carmona, A. E., R. A. Franqui and M. Otero, 2013. Survey of palm-associated Fulgoroidea in Puerto Rico. J. Agric. Univ. P.R. 97: 107-117.

Seín, F. 1933. Anastrepha (Trypetidae, Diptera) fruit flies in Puerto Rico. J. Dept. Agric. Labor P.R. 17: 183-196.

Seín, F. Jr., 1930. The sugar-cane root caterpillar and other root pests in Puerto Rico (Perforadix sacchari, new genus and species). J. Dept. Agric. Labor P.R. 14: 167-191.

Seín, F. Jr., 1923. Cucarachas. The Department of Agriculture and Labor. Circular 64. $12 \mathrm{pp}$.

Seín, F., Jr., 1923. Las abejas en los cafetales. The Department of Agriculture and Labor. Circular 79.6 pp.

Smith, C. F., 1970. Notes on the genus Picturaphis and related genera with a new species of Picturaphis from Puerto Rico (Aphididae: Homoptera). J. Agric. Univ. P.R. 54: 683-688.

Smith, C. F., 1960. New species of Aphidae: Homoptera from Puerto Rico. J. Agric. Univ. P.R. 44: 157-162.

Smith, C. F., Martorell and M. E. Pérez Escolar, 1968. La chinche de los pastos. Pub. Misc. Serv. Ext. Agric. 5M FA. 63:1-5.

Smith, C. F., L. F. Martorell and M. E. Pérez-Escolar, 1963. The Aphididae of Puerto Rico. Agric. Exp. Sta., Univ. P.R., Tech. Paper. 37: 1-121.

Smith, C. F., L. F. Martorell and M. E. Pérez-Escolar, 1958. Myzus persicae (Sulzer) in Puerto Rico. J. Agric. Univ. P.R. 42: 263-266.

Smith, C. F., S. Medina-Gaud, L. F. Martorell and M. Pérez-Escolar, 1971. Additions and corrections to the Aphididae of Puerto Rico. J. Agric. Univ. P.R. 55: 192-258.

Smith, M. B., 1936. The ants of Puerto Rico. J. Agric. Univ. P.R. 20: 819-875.

Smyth, E. G., 1920. The white grubs injuring sugar cane in Porto Rico. II. The rhinoceros beetles. J. Dept. Agric. P.R. 4: 3-29.

Smyth, E. G., 1919. An annotated bibliography of Porto Rican cane insects. J. Dept. Agric. P.R. 3: 117-134.

Smyth, E. G., 1919. List of the insects and mite pests of sugar cane in Porto Rico. J. Dept. Agric. Labor P.R. 3: 135-150.

Smyth, E. G., 1917. The white grubs injuring sugar cane in Porto Rico. I. Life histories of May-beetle (continued). J. Board Commissioners Agric. P.R. 1: 139-167.

Snelling, R. R. and J. A. Torres, 2004. The spider wasp of Puerto Rico. J. Kans. Entomol. Soc. 77: 356-76.

Snyder, F. M., 1957. Puerto Rican Neodexiopsis (Diptera Muscidae: Coenosinae). J. Agric. Univ. P.R. 41: 207-229.

Snyder, T. E., 1956. Termites of the West Indies, the Bahamas and Bermuda. J. Agric. Univ. P.R. 40: 189-202.

Telford, H. S., 1973. The Syrphidae of Puerto Rico. J. Agric. Univ. P.R. 57(3): 217-246.

Torres, J. A. and S. Medina-Gaud, 1998. Los insectos de Puerto Rico. Acta Cientifica 12: 3-41.

Torres, J. A., R. R. Snelling and M. Canals, 2000. New records of parasitoids of Aculeate Hymenoptera in Puerto Rico. J. Agric. Univ. P.R. 84: 99-100.

Townsend, J. I., 1955. Notes from Puerto Rican Drosophilidae, including descriptions of two new species of Drosophila. J. Agric. Univ. P.R. 39(2): 57-64.

Travers, J. R., 1938. Mayflies of Puerto Rico. J. Agric. Univ. P.R. 22: 5-42.

Tulloch, G. S., 1937. The brackish water mosquitoes of Puerto Rico. J. Agric. Univ. P.R. 21: $581-583$.

Tulloch, G. S., 1937. The mosquitoes of Puerto Rico. J. Agric. Univ. P.R. 21(2): 137-167.

Wolcott, G. N., 1956. The insects of "Almendrón" Prunus occidentalis Sw. J. Agric. Univ. P.R. 40: 203-204.

Wolcott, G. N., 1956. Batocera rubra Linnaeus in Puerto Rico. J. Agric. Univ. P.R. 40: 86.

Wolcott, G. N., 1955. Addendum to: "The insects of Puerto Rico". J. Agric. Univ. P.R. 39: 46. 
Wolcott, G. N., 1955. Dispersion to the tropics of the Spiraea aphid, Aphis spiraecola Patch. J. Agric. Univ. P.R. 39: 32-40.

Wolcott, G. N., 1948. The insects of Puerto Rico: Diptera and Lepidoptera. J. Agric. Univ. P.R. 32: 417-748.

Wolcott, G. N., 1948. The insects of Puerto Rico: Hymenoptera. J. Agric. Univ. P.R. 32: $749-975$.

Wolcott, G. N., 1948. The insects of Puerto Rico. J. Agric. Univ. P.R. 32: 1-224.

Wolcott, G. N., 1948. The insects of Puerto Rico: Coleoptera. J. Agric. Univ. P.R. 32: 225-416.

Wolcott, G. N., 1941. A supplement to insectae Borinquenses. J. Agric. Univ. P.R. 25: 33-158.

Wolcott, G. N., 1937. Two insects new to Puerto Rico: the Lycid Beethel, Thonalmus chevrolati Bourgeois, and the Ephydrid Fly, Ephydra gracilis Packard. J. Agric. Univ. P.R. 21: 535-538.

Wolcott, G. N., 1936. Insectae Borinquenses. A revised annotated check-list of the insects of Puerto Rico. J. Agric. Univ. P.R. 20: 1-600.

Wolcott, G. N., 1934. Lima bean pod-borer caterpillars of Puerto Rico on their wild hosts. J. Agric. Univ. P.R. 18: 429-434.

Wolcott, G. N., 1934. The present status of white grubs parasites in Puerto Rico. J. Agric. Univ. P.R. 18: 436-441.

Wolcott, G. N., 1933. The lima bean pod-borer caterpillar of Puerto Rico. J. Dept. Agric. Labor P.R. 17: 241-255.

Wolcott, G. N., 1924. Hormigas. The Department of Agriculture and Labor. Circular 75. $11 \mathrm{pp}$.

Wolcott, G. N., 1923. El Cucubano. The Department of Agriculture and Labor. Circular $80.8 \mathrm{pp}$.

Wolcott, G. N., 1923. First supplement to Insectae Portoricensis. J. Dept. Agric. Labor P.R. 7: 38-43.

Wolcott, G. N., 1923. Insectae Portoricensis, correction and additions. J. Dept. Agric. Labor P.R. 7: 313

Wolcott, G. N., 1923. Insectae Portoricensis. A preliminary annotated check-list of the insects of Porto Rico, with descriptions of some new species. J. Dept. Agric. Labor P.R. 7: 5-313.

Wolcott, G. N., 1922. Áfidos de importancia económica en Puerto Rico. The Department of Agriculture and Labor. Circular 59. $11 \mathrm{pp}$.

Wolcott, G. N., 1922. Insectos que atacan los productos almacenados. The Department of Agriculture and Labor. Circular 65. 8 pp.

Wolcott, G. N., 1922. Los gusanos de la hoja del tabaco. The Department of Agriculture and Labor. Circular 53. 15 pp.

Wolcott, G. N., 1922. Vaquitas de importancia económica en Puerto Rico. The Department of Agriculture and Labor. Circular 60.20 pp.

Wolcott G. N., 1921. The minor sugar-cane insects of Porto Rico. J. Dept. Agric. Labor P.R. 5: 5-46.

Wolcott, G. N., 1921. Los comejenes de Puerto Rico. The Department of Agriculture and Labor. Circular 44. 14 pp.

Wolcott, G. N. and F. Seín Jr., 1931. La oruga rosada de la cápsula del algodón. The Department of Agriculture and Labor. Circular 95. $13 \mathrm{pp}$.

Wolcott, G. N., J. D. More and F. Seín Jr., 1921. La oruga rosada de la cápsula del algodón en Puerto Rico. The Department of Agriculture and Labor. Circular 63. 11 pp.

Wolcott, G. N., and F. Seín Jr., 1922. Los caculos cornudos o los escarabajos rinocerontes de Puerto Rico. The Department of Agriculture and Labor. Circular 58. 13 pp.

Wray, D. L., 1953. New Collembola from Puerto Rico. J. Agric. Univ. P.R. 37: 140-150.

Wygodzinsky, P. and J. Maldonado-Capriles, 1972. Description of the first genus of physoderine assassin bugs (Reduviidae, Hemiptera) from the New World. Am. Mus. Novit. 2504: 1-7.

Young, D. A. Jr., 1953. Empoascan leafhoppers of the solana group with descriptions of two new species. J. Agric. Univ. P.R. 37: 151-160. 


\section{Further Research}

This work provides a compilation of the taxonomic contributions by the scientists who played a leading role in expanding knowledge of the insect fauna of Puerto Rico, and it presents a bibliography of their research papers. These are our legacies, available today through the publications in this paper describing the Puerto Rican insect fauna and serving as reference to numerous scientists and students doing research. Despite these contributions, much taxonomic research remains to be done in order to properly document the entomofauna of Puerto Rico (Franz and Yusseff-Vanegas, 2009; Maldonado-Capriles, 1996). Some groups are in great need of revision. After Wolcott's 1948 "The Insects of Puerto Rico", no publication treating the orders Diplura, Phasmatodea, Dermaptera, Embiidina, Zoraptera, Mantodea, Psocoptera, Trichoptera, and Strepsiptera was found.

Thanks to the pioneering work of Wolcott, Martorell, MaldonadoCapriles, Medina-Gaud, Mari-Mutt and many other entomologists we have a better understanding of the insect fauna of the island. A comprehensive faunistic study of the insects of Puerto Rico needs to be undertaken. As Maldonado-Capriles (1996) recommended, the first step should be to provide keys to the families and genera of the insect orders in Puerto Rico.

\section{ACKNOWLEDGMENTS}

Special thanks to the Organizing Committee of the Entomology Symposium for the invitation to participate as a speaker and the opportunity to take part in this special issue celebrating the 75th Anniversary of the International Institute of Tropical Forestry. My deep appreciation to Dr. Rosa A. Franqui, whose valuable comments contributed to this work and to Abdel Santiago for help with the literature review. This project was financed by a grant from the USDA Forest Service: 14-DG-11120107-021.

\section{LITERATURE CITED}

Barber, H. G., 1939. Insects of Porto Rico and the Virgin Islands: Hemiptera-Heteroptera (excepting the Miridae and Corixidae). In: Scientific Survey of Porto Rico and the Virgin Islands. Vol 14, Pt 3. New York: New York Academy of Sciences. pp 263-441.

Berríos-Ortiz, A., 1997. The Scientific Survey of Puerto Rico and the Virgin Islands: An Eighty-Year Reassessment of the Islands' Natural History by Julio C. Figueroa Colón. Isis: A Journal of the History of Science 88: 357.

Comstock, W. P., 1944. Insects of Porto Rico and the Virgin Islands: Rhopalocera or Butterflies. In: Scientific Survey of Porto Rico and the Virgin Islands. Vol 12, Pt 4. New York: New York Academy of Sciences. pp 421-622. 
Cook, M. T. and J. I. Otero, 1937. History of the first quarter of a century of the Agricultural Experiment Station at Río Piedras, Puerto Rico. Bull. 44. Agric. Exp. Stn. $123 \mathrm{pp}$.

Curran, C. H, 1928. Insects of Porto Rico and the Virgin Islands. Diptera or two-winged flies. In: Scientific Survey of Porto Rico and the Virgin Islands. Vol 11, Pt 1. New York: New York Academy of Sciences. 118 pp.

Forbes, T. M., 1931. Supplementary report on the Heterocera or moths of Porto Rico. J. Agric. Univ. P.R. 15: 339-394.

Forbes, T. M, 1930. Insects of Porto Rico and the Virgin Islands. Heterocera or moths (excepting the Noctuidae, Geometridae and Pyralidae). In: Scientific Survey of Porto Rico and the Virgin Islands. Vol 12, Pt 1. New York: New York Academy of Sciences. $171 \mathrm{pp}$.

Franqui, R. A., J. A. Santiago-Blay and S. Medina-Gaud, 1997. The "Museo de Entomología y Biodiversidad Tropical" of the Agricultural Experiment Station, University of Puerto Rico. Fla. Ent. 80: 490-492.

Franz, N. M. and S. Z. Yusseff-Vanegas, 2009. The University of Puerto Rico at Mayagüez insect collection-then and now. Ent. News 120: 401-408.

Genaro, J. A. and N. M. Franz, 2008. The bees of Greater Puerto Rico (Hymenoptera: Apoidea: Anthophila). Insecta Mundi 40: 1-24.

International Commission on Zoological Nomenclature (ICZN), 1999. International Code of Zoological Nomenclature. London: The International Trust for Zoological Nomenclature. $306 \mathrm{pp}$.

Klots, E. B., 1932. Insects of Porto Rico and the Virgin Islands: Odonata or dragon flies. In: Scientific Survey of Porto Rico and the Virgin Islands. Vol 14. New York: New York Academy of Sciences. $107 \mathrm{pp}$.

Lawrence, P. O., 2000. The pioneering work of George N. Wolcott: Implications for U.S.Caribbean entomology in the 21st century. Fla. Ent. 83: 388-399.

Lingafelter, S. W. and C. J. Micheli, 2004. New species of cerambycidae (Coleptera) from Puerto Rico with records and notes for other species. J. New York Entomol. Soc. 112: $37-55$.

Lugo, A. E., 2016. The Scientific Legacy of Juan A. Torres Negrón. Proc. Entomology Symp: Legacy of the International Institute of Tropical Forestry. Río Piedras, 17-18 March, 2016, p 1.

Maldonado-Capriles, J., 1996. The status of insect alpha taxonomy in Puerto Rico after the Scientific Survey, pp 201-216. In: J. C. Figueroa Colon (ed) The Scientific Survey of Puerto Rico and the Virgin Islands: An Eighty-Year Reassessment of the Islands' Natural History. Vol. 776. Annals of the New York Academy of Sciences. 273 pp.

Maldonado-Capriles, J. and S. Medina-Gaud, 1985. Insectos dañinos y beneficiosos de Puerto Rico. (Manual de Laboratorio). Librería Universal, Inc. Mayagüez, PR. 200 pp.

Martorell, L. F., 1976. Annotated Food Plant Catalog of the Insects of Puerto Rico. University of Puerto Rico, Agricultural Experiment Station, Río Piedras, Puerto Rico. $303 \mathrm{pp}$.

Martorell, L. F., 1973. The Insects of Mona Island, Puerto Rico. In: Isla de Mona- Volumen II: Junta de Calidad Ambiental. J1-7 pp.

Medina-Gaud, S., 2006. The Muscidae (Insecta: Diptera of Puerto Rico). University of Puerto Rico, Mayagüez Campus, Agricultural Experiment Station, Department of Crop Protection. XXI, $224 \mathrm{pp}$.

Medina-Gaud, S., 2002. Luis Felipe Martorell Dávila, 1909-2002, Biografía, Patrimonio y Lista de Publicaciones. J. Agric. Univ. P.R. 86: 85-94.

Micheli, J. A., 2010. Longicornios de Puerto Rico (Coleoptera: Cerambycidae). Pensoft Publisher, Sofia. 226 pp 72 plates.

New York Academy of Sciences, 1946. Publication List of The Scientific Survey of Porto Rico and the Virgin Islands. Retrieved from http://dspace.cai.sg.inter.edu/xmlui/bitstream/handle/123456789/15358/BP1c003d034.pdf? sequence $=1$

Osborn, C. H., 1935. Insects of Porto Rico and the Virgin Islands: Homoptera (excepting the Sternorrhyncha). In: Scientific Survey of Porto Rico and the Virgin Islands. Vol 14, Pt 2. New York: New York Academy of Sciences. pp 111-260. 
Ramos, J. A., 1957. Review of the Auchenorrhynchous Homoptera of Puerto Rico. $J$. Agric. Univ. P.R. 41: 38-117.

Ramos, J. A., 1946. The Insect of Mona Island (West Indies). J. Agric. Univ. P.R. 30(1): 1-74.

Santiago-Blay, J. A., 1997. Obituary Jenaro Maldonado-Capriles 1919-1995: Biographical sketch, patronyms in his honor, and list of publications. Proc. Entomol. Soc. Wash. 99: 762-771.

Schaus, W., 1940a. Insects of Porto Rico and the Virgin Islands: Moths of the family Noctuidae. In: Scientific Survey of Porto Rico and the Virgin Islands. Vol 12, Pt 2. New York: New York Academy of Sciences. pp 177-290.

Schaus, W., 1940b. Insects of Porto Rico and the Virgin Islands: Moths of the family Geometridae and Pyralidae. In: Scientific Survey of Porto Rico and the Virgin Islands. Vol 12, Pt 3. New York: New York Academy of Sciences. pp 291-417. 